Article

\title{
Developing an Open Space Standard in a Densely Populated City: A Case Study of Chittagong City
}

\author{
Maharina Jafrin ${ }^{1, *}$ and Beau B. Beza ${ }^{2}$ D \\ 1 Faculty of Science Engineering \& Built Environment, Deakin University, Victoria 3220, Australia \\ 2 Associate Head of School-Teaching \& Learning, Faculty of Science Engineering \& Built Environment, \\ Deakin University, Victoria 3220, Australia; beau.beza@deakin.edu.au \\ * Correspondence: mjafrin@deakin.edu.au; Tel.: +61-470-273-640
}

Received: 30 May 2018; Accepted: 11 September 2018; Published: 19 September 2018

\begin{abstract}
In densely populated settings like Chittagong, Bangladesh cities facing rapid urbanization and economic growth are challenged to provide open space for its citizens. For example, the population of this port city is 14,200 people per square kilometer and there is a struggle to provide open space. Again, the planning proposal did not set any open space standard to achieve its open space aspirations Hence, the objectives of this paper are four-fold: (i) Develop an understanding of open space standards to establish relative benchmarks for potential use in Chittagong. (ii) Examine existing formal open space in Chittagong. (iii) Document the existing informal open space areas in Chittagong according to the planning direction. (iv) Recommend an approach that can be used to realize open spaces in Chittagong. To achieve these, this paper documents the existing open space scenario in the city, examines the recommended open space standards developed by organizations such as the World Health Organization (WHO) and the Dhaka Structural Plan (2016-2035) (the planning document of the capital city of Bangladesh) to identify to what extent these 'benchmark' standards are appropriate for use in the city. A discussion on open space in Chittagong and the criteria used to 'frame' open space calculations in the city is then conducted to provide a foundation to reflect upon the world's various open space recommendations. Ultimately, by analyzing existing open space recommendations and their associated well-being aspirations, the research suggests that a new standard relating to the unique characteristics of the city should be used when developing open space standards in Chittagong.
\end{abstract}

Keywords: open space; WHO; Dhaka; Structural Plan; Chittagong

\section{Introduction}

Chittagong has a population of 4.1 million people in 168.1 square kilometers of land. The city is the commercial capital and largest port of Bangladesh and faces rapid urbanization; which has resulted in a loss of the city's existing open spaces due to the city's increasing development. An early response to this open space loss came in 1961, when the first regional plan in Chittagong was formulated. This document is of particular importance because it noted, for the first time, the city's lack of public parks, playgrounds, and small children's play areas. The plan also proposed 26 new parks and other open spaces to meet the needs of the city's population. The proposed accumulated area to provide for these spaces consisted of 2935 acres of land, which was largely scattered around the city in small parcels. While cities around the world are struggling to keep a standard amount of open space, the WHO suggested a standard of 9 square meter per capita, the cumulative existing open space in Chittagong is 0.18 square meter per person. Furthermore, the WHO suggested that the availability, accessibility, quality, and security of public green spaces may vary in metropolitan regions, this so-called green environment is one of the indicators of healthy cities [1]. However, poor cities are far from the international minimum standard set by WHO of 9 square meters open space 
per city dweller [2]. The open space standard is to provide sufficient outdoor recreation facilities to the residents of a city. In addition, improved air and water quality, buffering of noise pollution, and mitigation of impacts from extreme events, urban open spaces can reduce environmental health risks associated with urban living [3]. Open space priorities will be different in different settlement types. These should compensate and complement the physical and social context of the surrounding environment [4]. As an example, FIT (Field in Trust), the former NFPA (National Playing Fields Association) in Britain fix, started open space standards in 1925 to provide playing facilities to residents according to age group [5]. Hence, open space standards help to set a well-distributed network of space in a city to serve the resident by placing in proximity. Therefore, open space standards need to be sorted according to local and physical context. In a dense setting, a good standard depends on provision, distribution, accessibility, connectivity, diversity, size, shape, and quality [6].

Land use change in Chittagong, from open space, vegetation, and waterbodies to urbanized settings occurred from 1989 to 2001 where open areas were reduced by 76\%. Then from 2001 to 2013 a further reduction was noted, this time a reduction of these spaces occurred by another $72 \%$ [7]. The implication of this reduction was noted by Hassan (2008), where it was estimated that, in 2006, Chittagong had 132.7 acres of open space that served only $3 \%$ of the city's demand [8]. Earlier, however, Hossain (2002) attempted to determine the city's existing open spaces and water body acreage in the 1961 Master Plan of Chittagong City. She found and mentioned that; "[we] currently have an open space average of 0.066 acres per 1000 population, we have failed miserably to promote the development of parks, playfields, and other amenity open spaces needed" [9]. Unfortunately, this failure appears to be becoming more pronounced as the city's population grows. Every year, for example, on average, the population inside the city's area increases by approximately 77,625 people [10]. Because of this increasing population, to meet the growing demand for open spaces, it can be estimated from Private Housing Rules in Bangladesh that Chittagong will need an additional 0.036 square kilometers of park land and 0.024 square kilometers of playgrounds per person within the city area [11].

\section{Research Objectives and Methodology}

The above discussion suggests that Chittagong does not have adequate open space to meet its existing and growing population. In fact, open space is decreasing at an alarming rate and is accompanied by the planning authority's lack of understanding of the varied open space typologies found in the city. This paper is an attempt to conduct an open space database of Chittagong by analyzing the provision of open space in master plans. Hence, the objectives of this research are:

- Develop an understanding of international open space standards to establish relative benchmarks for potential use in Chittagong.

- Examine existing formal open space in Chittagong.

- Document the existing informal open space areas in Chittagong according to planning direction.

- Recommend an approach that can be used to realize open spaces in Chittagong.

By addressing the above objectives this research plans to contribute to the establishment of an open space standard relating to a developing urban setting, which will support the Chittagong' planning authority in their effort to create and maintain open space in the city. The research will also present an open space typology and model that can be used by other densely populated cities in emerging nations that lack open space infrastructure. In addition, the creation of an open space model will not only suggest an adequate open space benchmark for Chittagong's residents but can also play a role in addressing issues that affect peoples' quality of life, health, and safety. Furthermore, the standard will help with the planning of open spaces of different typologies, while the benchmark will help the planner control and preserve open space where necessary.

The methodology used in this research is based on a review of frameworks related to open space benchmarks and typology recommended by organizations, such as the WHO, National Recreation and Park Association (NRPA), and Greenspace Scotland. Following this review, the next section focuses 
on a theoretical discussion of Chittagong's existing open spaces and the planning proposals intended to improve the city's open space situation. Location and topography (height) and their effect on influencing the 'accessibility' of open space in Chittagong is discussed using material generated from the city's GIS database; which has been provided by the Chittagong Development Authority (CDA). Google Maps and Google Earth mapping information related to the City are overlaid onto this GIS material to help illustrate the data. Essentially, the research uses a case study approach, as explained by Yin [12], to investigate the contextual conditions in a single and extreme case, found in Chittagong city's open space, by critically examining the master plan for Chittagong.

\section{Understanding Open Space Standard}

Open space as a ventilation space in a city is a determining factor of the health of the community [13]. An open space standard includes a needs-based assessment that considers population numbers, density, demographic profiles, and recreation preferences [14]. The paper focuses on developing an open space standard for Chittagong to compare to the current city standard and how it can make more of what it has. In the context of planning for a city-wide open space agenda, the term standard in reference to open space requirements is referred to, in this instance, as a mechanism to help address change in the City for the betterment of its residents. However, before this reference can be applied it must first be noted that the open space standards used throughout the world are determined by a number of indicators and their use for open space planning has a long history, dating back to the nineteenth century [15]. Throughout the 20th century, formal national standards for open space planning were developed, notably, in Britain and in the United States [16]. In Britain the National Playing Fields Association (NPFA), now Fields in Trust (FIT), standard of 6 acres of open space per 1000 population (24 square meter per capita) has been in existence since the 1920s, while in the USA, the National Recreation Association (now National Recreation and Parks Association, NRPA) standard of 10 acres of open space per 1000 population ( 40 square meter per capita) dated from early in the twentieth century [16].

What can be assumed by this short 'list' of countries and open space examples is that their respective standards reflect a number of specific country related indicators and these vary in relation to their cities. They also reflect the priorities and agendas of local planning bodies. Yet, the most commonly used indicator, in these settings, is a Quantity Standard, which is derived from examination, by city officials, of their open spaces related to a population of 1000 or by square meter per capita. The other standard, quality, is largely overlooked as a mechanism to achieve open space aspirations and address safety and user's satisfaction. Accessibility is another open space-related standard which is discussed in the next section of this paper to discuss the area of Chittagong that has been deprived from open space facility.

The following table is a conceptual attempt to organize the open space standards used in the countries of America, Australia, Europe, and Asia. This figure should not be viewed as a comprehensive work or for the purposes of criticizing country specific standards. Rather it should be viewed as an illustration suggesting an abstract weighting of a respective country's standards that affect the realization of open space aspirations in a setting.

Table 1 shows that in the USA and UK, countries measure open space standards by four indicators. These are quantity, quality, accessibility, and neighborhood or locality; whereas in Australian states and territories, only the first three indicators are used. In comparison, Asian countries like Hong Kong and Kuala Lumpur use both quantity and accessibility standards. Whereas, India only uses the quantity indicator to measure open space standard. As the table suggests, there are a range of standards and open space priorities in each of the respective country settings. Each set of standards also appears to follow and is prescribed along a specific cultural context. According to the above table, the following three standards are the most commonly practiced: 
Table 1. Indicators of open space standards in American, Australian, European, and Asian countries.

\begin{tabular}{|c|c|c|c|c|}
\hline \multicolumn{5}{|c|}{ Organization: National Recreation and Park Association (NRPA), USA } \\
\hline \multicolumn{5}{|c|}{ Guidelines: NRPA Park Metrics } \\
\hline Quantity & Quality & Accessibility & \multicolumn{2}{|c|}{ Neighborhood/locality } \\
\hline \multicolumn{5}{|c|}{ Greenspace Scotland and Scottish Natural Heritage (2013) } \\
\hline Quantity & Quality & Accessibility & \multicolumn{2}{|c|}{$\begin{array}{l}\text { A series of settlement or } \\
\text { neighborhood descriptions }\end{array}$} \\
\hline \multicolumn{5}{|c|}{ Fields in Trust (fit) UK } \\
\hline \multicolumn{5}{|c|}{ Guidance for Outdoor Sport and Play: Beyond the Six Acre Standard } \\
\hline $\begin{array}{c}\text { 1. Quantity } \\
\text { 2. Spatial Requirements }\end{array}$ & Quality & Accessibility & \multicolumn{2}{|l|}{ Buffer zones } \\
\hline \multicolumn{5}{|c|}{ Parks and Leisure Australia [17], Open space planning standards in Australia } \\
\hline 1. Population-ratio & \multirow{2}{*}{ Facility specification } & \multirow{2}{*}{ Catchment Area } & \multirow{2}{*}{\multicolumn{2}{|c|}{$X$}} \\
\hline 2. Area-percentage & & & & \\
\hline \multicolumn{5}{|c|}{ Hong Kong, Planning Department, Principals of Recreation and open space planning } \\
\hline Population standard & $\mathrm{x}$ & Greening standards & $X$ & \\
\hline \multicolumn{5}{|c|}{ Federal Territory of Kuala Lumpur, Department of Statistics, Malaysia } \\
\hline Quantity & $\mathrm{x}$ & Accessibility & $\mathrm{X}$ & D. \\
\hline \multicolumn{5}{|c|}{ Town and Country Planning Organization (GOI) in India } \\
\hline \multicolumn{5}{|c|}{ Urban and Regional Development Plans Formulation \& Implementation (URDPFI) Guidelines } \\
\hline \multicolumn{5}{|l|}{ Quantity } \\
\hline \multicolumn{5}{|c|}{ Ministry of Housing and Public works, Government of Bangladesh } \\
\hline Quantity & & & & \\
\hline
\end{tabular}

I. Accessibility standard

II. Quality Standard

III. Quantity standard

To aid in the discussion of Chittagong's open space development this paper focuses on examining the accessibility and quantity standard of Chittagong's existing open spaces. This is done in an attempt to understand the extent to which a shortage of open space is currently occurring in the city. These two indicators (accessibility and quantity) need to be reviewed and focused on as they represent dimensions of the existing open space shortage currently being addressed in the City's planning proposals and little material is found on these. Other data, for example quality standard, however, does exist, which is on the level of satisfaction of safety and security of parks and playgrounds in Chittagong [8].

I. Accessibility standard: The accessibility standard refers to how close people should be to their nearest publicly usable open space [18]. So, accessible green spaces are defined as places available free of cost to the people, and are mainly utilized by target users living in the catchment area [17]. International research into the impacts of greenspace on health and on wider quality of life shows that having greenspace within a 5-min walk of home is a strong indicator for health and quality of life benefits [19]. There are several methods developed to measure accessibility. Bangladesh does not have any accessibility standard for Chittagong to follow. But according to walkability of $400 \mathrm{~m}$, the accessibility scenario is as shown in the Figure 1 (paid and restricted entries are ignored due their accessibility restrictions). The figure shows that the open spaces are mostly concentrated in the old town, but it is a necessity if they are accessible in terms of connectivity to surroundings by walkways. 


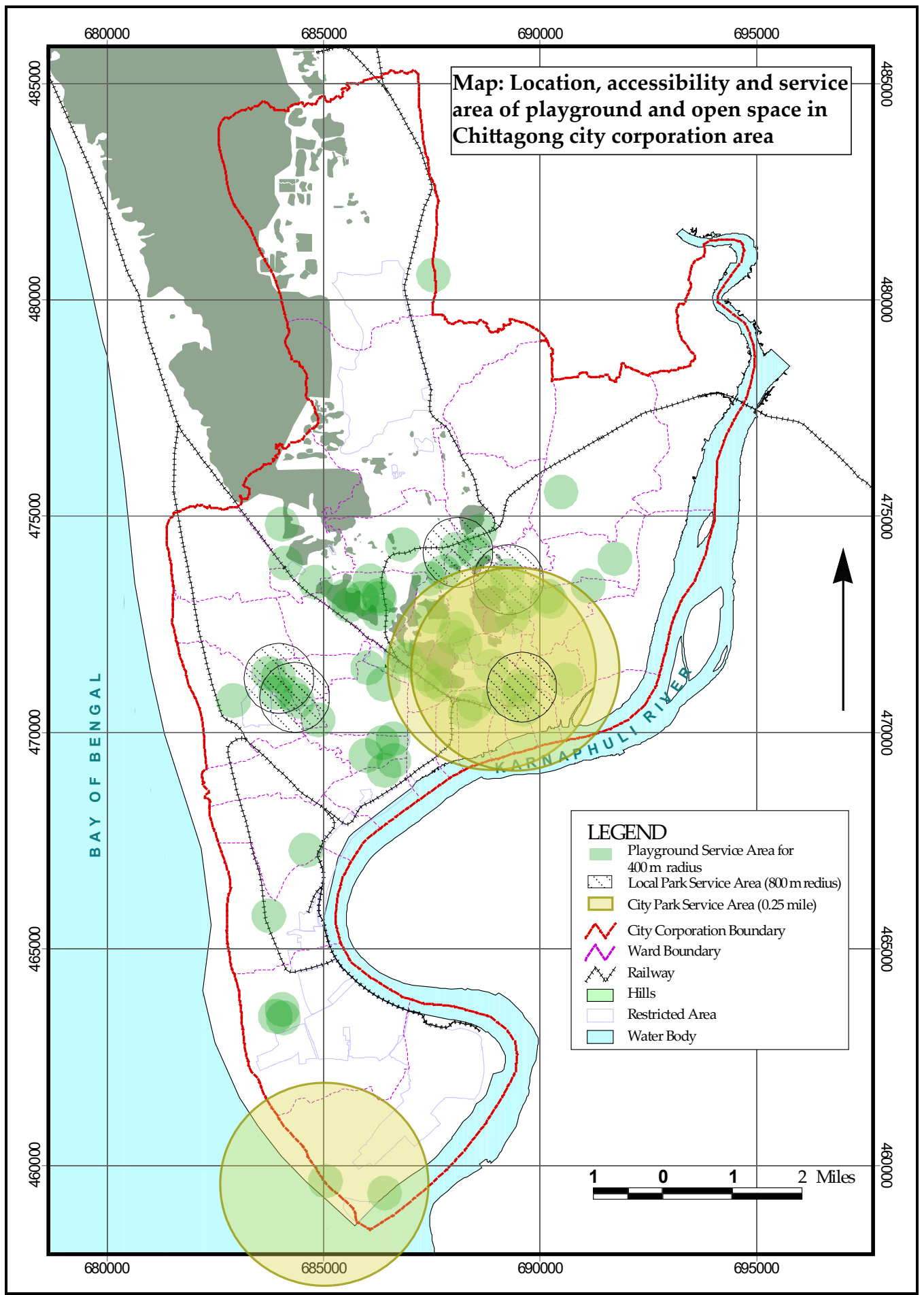

Figure 1. Existing open space accessibility scenario according to 5-min walk. Source: updated by author.

A total of 69 local parks and playgrounds of Chittagong will have a catchment area. From the equation, area of a circle, this catchment area is $A=\pi r^{2} \times 69=34,683,182$ square meter or 34.68 square kilometer of land, which is only $20 \%$ of the whole city.

II. Quality Standard: The quality standard is a matrix that identifies what infrastructure or landscape features are appropriate and suited for open spaces that satisfy the users [17]. All publicly usable open spaces score 'good' or better on the locally used quality assessment. A report by Hassan 
(2008) on quality of seven parks and 13 playgrounds shows that the satisfaction levels of Park users are relatively better than Playground users in Chittagong.

III. Quantity Standard: The quantity standard also varies with locality. Quantity is based on existing open space provision. All settlements/neighborhoods should have $\mathrm{X}$ hectares of publicly usable open space per 1000 people (or $\mathrm{Ym}^{2}$ per household)—where $\mathrm{X}$ or $\mathrm{Y}$ is locally derived.

Quantity benchmarks related to the above standards vary in different cities. For example, the majority of councils in Australia apply the open space standard of 7 acres/1000 population or $28 \mathrm{~m}^{2}$ per capita [20]. In Chittagong this type of ratio is beyond the consideration of planners because Australian cities (such as Sydney) are suggested to be not as densely populated when compared to European and Asian Cities [15]. While density is an issue in fixing the open space standard as a physical feature, a comparison of Chittagong and, say, Melbourne may revolve around the respective city's approximate size (i.e., area), population, and relative density along with clearly stating how/where metropolitan borders are framed and what is included (or not) as open space.

For example, the World Health Organization (WHO) recommends $9 \mathrm{~m}^{2}$ of open space per person. Cities such as Tokyo, Hong Kong, and Buenos Aires strive to meet this standard (or other open space benchmarks) [21]. Hence, a standard one size fits all ratio, such as that developed by the WHO, may not be appropriate in setting like Chittagong. Table 2, below, identifies the relative open space per capita ratio in cities considered to be the fastest growing and most densely populated. The cities considered developing and fast growing according to UN habitat are taken for this comparison [22]. The UN habitat suggests that Maxico, Buenos Aires in Latin America, Dhaka, and Mumbai in South Asia are developing cities. Istanbul and Kuala Lumpur are also taken into consideration as Turkey and Malaysia are the fastest growing rapid urbanizing countries [22]. Though China is also a rapidly growing country, the mega cities of China like Beijing and Shanghai have a reasonable area of open space compared to their density. The Chittagong master plan did not propose any standard to follow; Dhaka Structural Plan (2016-2035) can be taken as reference, While Dhaka city has only $0.16 \mathrm{~m}^{2}$ open space. The table below presents the cities that have an open space ratio below the WHO standard.

Table 2. Open space in cities below the WHO recommended standard.

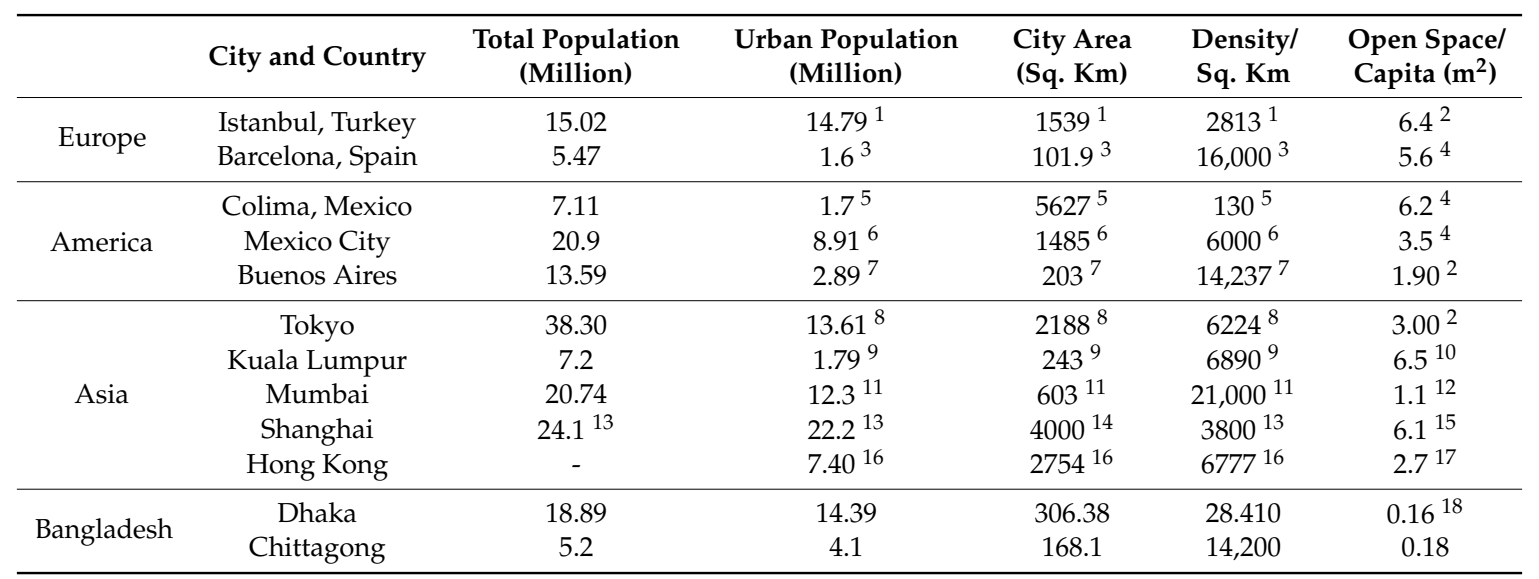

1 Turkish Statistical Institute Turkish demographics and statistics; ${ }^{2}$ [23]; ${ }^{3}$ Department of Statistics of Catalonia-Population, household and homes statistics; ${ }^{4}$ [24]: ${ }^{5} \mathrm{http}: / /$ www.citypopulation.de/Mexico-Colima. html; ${ }^{6}$ Mexico Demographics Profile 2018; ${ }^{7}$ Censo 2010. Resultados provisionales: cuadros y gráficos; ${ }^{8}$ Tokyo Metropolitan Government; ${ }^{9}$ "Federal Territory of Kuala Lumpur". Department of Statistics, Malaysia;

${ }^{10}$ Appendix A; 11 "Maharashtra (India): Districts, Cities, Towns, and Outgrowth Wards-Population Statistics in Maps and Charts"; ${ }^{12}$ https: / / timesofindia.indiatimes.com/ city/mumbai/You-have-just-1-1-square-metres-ofopen-space/articleshow/13585198.cms; ${ }^{13}$ The operation of the national economy in Shanghai in 2017 (in Chinese). Shanghai Bureau of Statistics. 19 January 2018. Retrieved 10 August 2018; ${ }^{14}$ "Land Area". Basic Facts. Shanghai Municipal People's Government. Retrieved 10 August 2018; ${ }^{15}$ [25]; ${ }^{16}$ Monthly Statistics for June 2018, p. 4; 17 "Population \& Housing Census-2011" (PDF). Bangladesh Bureau of Statistics. p. 4; ${ }^{18}$ Dhaka Structure plan 2016-2035 Chapter 10 Preserving open space for recreation, livability and identity, p 213. 


\section{Existing Open Space Ratio in Chittagong and Its Management}

Currently, there are 81 official and unofficial open space areas within Chittagong, and combined, they occupy 325.43 acres of land. These spaces can be categorized into seven different existing open space typologies; which are discussed in the following section. Table 1 identifies the distribution of open space in the city. Interpreting data from this table suggests that Chittagong has only 0.0476 acres of open space per 1000 people or $0.18 \mathrm{~m}^{2}$ per person (the amusement parks, zoo, and zoological park is excluded due to paid entry). According to the data in the table, the amount open space related to a Local (municipal) Park is very low; in both number and size. The impact of this is twofold: the city is not providing adequate local open space for its citizens and the residents of Chittagong do not have green space and urban places (e.g., plaza and streets) to realize the openness in a congested setting.

To address the city's shortage of open space, and in relation to private land ownership and paid entry into open space (e.g., the amusement park identified above), the City's Detailed Area Plan (DAP) suggests that expropriation and compensation of such land to acquire open space in Chittagong is a strategy worth pursing, as it can help address the city's loss of 'green' space. The document continues to propose the adoption of innovative measures to generate revenue from such lands. However, none of these proposals were implemented. While this plan is being enacted, DAP guidelines on land use must be followed; which accounts for and allows development in privately owned open space. In the hopes of better managing these spaces and other open spaces the DAP has recommended the creation of a department titled: Chittagong Parks and Recreation Department. The intention with the creation of this department is to be incorporated within the Chittagong City Corporation [4]; who, in itself, maintains a close liaison role with the City's planning authority which is charged with acquiring, designing, and maintaining parks and open space; while the Master Plan and DAP provide guidelines to preserve unofficial open spaces in the city. Table 3 also identifies a lean towards quantification rather than quality or accessibility of open space; which in terms of the former data that is easily accessible in the City's open space related documents.

Table 3. Distribution of existing open space in Chittagong.

\begin{tabular}{|c|c|c|c|c|c|c|c|}
\hline \multirow{2}{*}{$\begin{array}{l}\text { Sl. } \\
\text { No }\end{array}$} & \multirow{2}{*}{ Type } & \multirow{2}{*}{ Number } & \multicolumn{2}{|c|}{ Total Area } & \multicolumn{2}{|c|}{$\begin{array}{l}\text { Space Allocation per } \\
1000 \text { Population }\end{array}$} & \multirow{2}{*}{$\begin{array}{c}\% \text { of Area Compare } \\
\text { to City Area }\end{array}$} \\
\hline & & & Acre & Hectare & Acre & Hectare & \\
\hline 1 & $\begin{array}{l}\text { Amusement } \\
\text { Park }\end{array}$ & 4 & 120.90 & 48.56 & - & - & $0.28 \%$ \\
\hline 2 & Zoo & 1 & 4.2 & 1.69 & - & - & $0.009 \%$ \\
\hline 3 & Zoological park & 1 & 3.89 & 1.57 & - & - & $0.008 \%$ \\
\hline \multicolumn{8}{|c|}{ Park and playground } \\
\hline 4 & City park & 3 & 46.24 & 18.71 & 0.0111 & 0.004 & $0.20 \%$ \\
\hline 5 & Local park & 5 & 8.7 & 3.52 & 0.0021 & 0.0008 & $0.02 \%$ \\
\hline 6 & Playground & 64 & 106 & 42.89 & 0.0258 & 0.0104 & $0.24 \%$ \\
\hline \multicolumn{8}{|c|}{ Sports Complex } \\
\hline 7 & Stadium & 2 & 35.5 & 14.37 & 0.0086 & 0.0034 & $0.08 \%$ \\
\hline & Grand Total & 81 & 325.43 & 131.69 & 0.0476 & 0.0192 & $0.837 \%$ \\
\hline
\end{tabular}

In relation to the open space areas, identified in the above table, a variety of agencies in Chittagong are responsible for their development and management. In addition to this, regarding the open space planning regime, the CDA and the CCC are largely responsible for the management of the municipal open space systems within the City. The CDA is specifically responsible for planning, conservation, and the implementation of open space. Whereas the CCC is responsible for maintenance of official open space within Chittagong. The management of the City's waterways and sewage is managed by the District Commissioner's Office and Chittagong Water supply, and the Swage Authority (CWASA), respectively [26]. The Bangladesh Navy (BN) and Chittagong Port Authority (CPA) are engaged in riverside open space management, which contributes to the planning and development of the City's 
waterfront. The Bangladesh Navy (BN) and Chittagong Port Authority (CPA) are engaged in riverside open space management, which contributes to the planning and development of the City's waterfront.

To bring these varying open space management organizations together according to the DAP, the city's planning authority and the CCC/local government are to establish cooperation between private land owners, private developers, companies, the government, environmentalists, and professionals to establish a system of open spaces that is made up of hills, ponds, gardens, walking and cycling paths, and tree-lined boulevards [10]. In essence, these authorities desire to bring together all the various open space management groups under one umbrella with the intent to plan and coordinate the city's future open space direction. According to the CCC Ordinance, the Corporation, if required by the government, shall layout and maintain public places as may be necessary for the recreation and convenience of the public, such as those related to public gardens and open spaces.

\section{Open Space Planning Standards and for Bangladesh}

In the 1961 Master Plan for Chittagong, the open space recommendations received negligible attention by the City's officials [10]. The recommendation was to increase open space by providing twenty-six proposals which were made by arbitrarily selecting sites to preserve for future need. Later, in 2004, guidelines and a planning standard for parks and playgrounds were established for the City's Private Housing Projects by the Ministry of Housing and Public Works, Bangladesh. The following standards have been adopted for open spaces for land development rules for private housing and suggest that the City's natural green areas like City Park, the Botanical Garden, or water bodies are excluded from this structure. The Detailed Area Plan of Chittagong provides guidelines for the conservation of open spaces, while the direction on open space standard and the cumulative figure of existing open space is overlooked in DAP. Chittagong follows the following standards for developing private housing projects under the supervision of the Chittagong Development Authority (CDA). However, these standards relate to, and provide for, open space in private residential areas. The requirements are:

- Local Park: 0.12 Acre/1000 people or 0.48 square meter/capita

- Playground: 0.08 Acre/1000 people or 0.32 square meter/capita

- Total 0.20 Acre/1000 people or 0.80 square meter/capita

Hassan (2008) suggests that an open space standard in Chittagong of 1.8 acre/1000 population or 7.28 square meters per capita would be hard to achieve when the City's existing open space is currently 0.18 square meters per capita. Additionally, the proposal was also made by taking the suggestion of officials and adding selective Master Plan proposals while ignoring the distribution of typology and accessibility of residents.

Again, Table 4 shows that the proposed standard of open space in four cities of Bangladesh each fall below the recommended WHO standard. Furthermore, the existing open space ratios identified in these cities are below the recommended standard for open space in Bangladesh. As an example, open space in Dhaka is at a level of $0.16 \mathrm{~m}^{2}$ per person; which is well below the standard recommended in the city's master plan. Again, it is noticed that, DMDP (1995-2015) proposed $3.8 \mathrm{~m}^{2} /$ capita open space for park and playground was proposed additional $1.3 \mathrm{~m}^{2} /$ capita, which has been revised in Dhaka Structural Plan (2016-2035) as $3.5 \mathrm{~m}^{2}$ for both parks and play fields [27]. 
Table 4. Open space standards recommended in planning proposals of metropolitan cities of Bangladesh [28].

\begin{tabular}{ccccc}
\hline Unit & $\begin{array}{c}\text { Khulna City } \\
\text { Master Plan, } \\
\text { 2001-2010 }\end{array}$ & $\begin{array}{c}\text { Dhaka Metropolitan } \\
\text { Development Plan, } \\
\text { 1995-2015 [18] }\end{array}$ & $\begin{array}{c}\text { Rajshahi Urban } \\
\text { Area/Functional Master } \\
\text { Plan, 2004-2024 }\end{array}$ & $\begin{array}{c}\text { Barishal Master } \\
\text { Plan 2010-2030 }\end{array}$ \\
\hline $\begin{array}{c}\text { Per 1000 } \\
\text { population }\end{array}$ & 2 acre & 0.96 acre & 1.5 acre & 1 acre \\
Per capita & $8 \mathrm{~m}^{2}$ & $3.8 \mathrm{~m}^{2}$ & $6 \mathrm{~m}^{2}$ & $4 \mathrm{~m}^{2}$ \\
\hline
\end{tabular}

In order to help establish a relative target to aspire to in Chittagong over a specific time frame, it is important to review the types of open space found in the City and their association in this setting's urban catchment areas. Hence, the availability of open space needs to be revisited as this potentially influences the recommendation of open space standards for Chittagong. The following section examines the existing open space scenario in the Chittagong with the view of identifying and cataloging the various open spaces used by the city's residents by following the typology of open space in cities.

\section{Categorization of Open Space}

There are generally two methods used in open space categorization i.e., 'Typology' and 'Classification'. Typology refers to the type of open spaces regardless of their inner character. In fact, the typology method mainly focuses on type of spaces such as 'Squares' 'Plazas', 'Atrium/ Indoor/Marketplaces', 'Streets', 'Residential', 'Parks', 'Markets', and so on [29]. Open space character is influenced by a range of factors such as location, level of development, primary function, and interface with adjoining land use and urban form [30].

Classification is used when the characters of spaces are included in the categorization. In addition, open space has different characteristics, and this influences the way in which open space is used and valued [31]. The classification system is to be applied in conjunction with the 'Site Analysis and Context Assessment' and 'Precinct Objective'. The idea being that the site analysis, context assessment, and precinct objectives will have identified those characteristics of a site, and its surrounds that should be reinforced and those that may pose constraints. The classification method in classifying open spaces generally covers three approaches, (i) the catchment hierarchy (who will use the open space), (ii) function (the role of the open space), and (iii) landscape/environmental character (what the open space looks like) [32]. Figure 2 shows the inclusive view of open space categorization.

\subsection{Function}

Each open space is assigned with a functional classification to reflect its primary use, used to define the purpose planned for a space, and a functional classification, considering the primary purpose or use of the open space within the network [33]. Primary use and expected activities identified three primary functions of open spaces [32].

Recreation spaces: Recreation spaces provide a setting for informal play and physical activity, relaxation, and social interaction. Recreation spaces enhance physical and mental health through activity that provides relaxation, amusement or stimulation [32].

Sport spaces: Sport spaces provide a setting for formal structured sporting activities. Sport spaces provide a venue for formal, structured sporting activities such as team competitions, physical skill development, and training [32].

Nature spaces: Nature spaces provide a setting where people can enjoy nearby nature and protect local biodiversity and natural area values. Nature spaces provide opportunity for low-impact recreational activities, such as walking, cycling, picnicking, playing, watching, or exploring natural features [32]. 


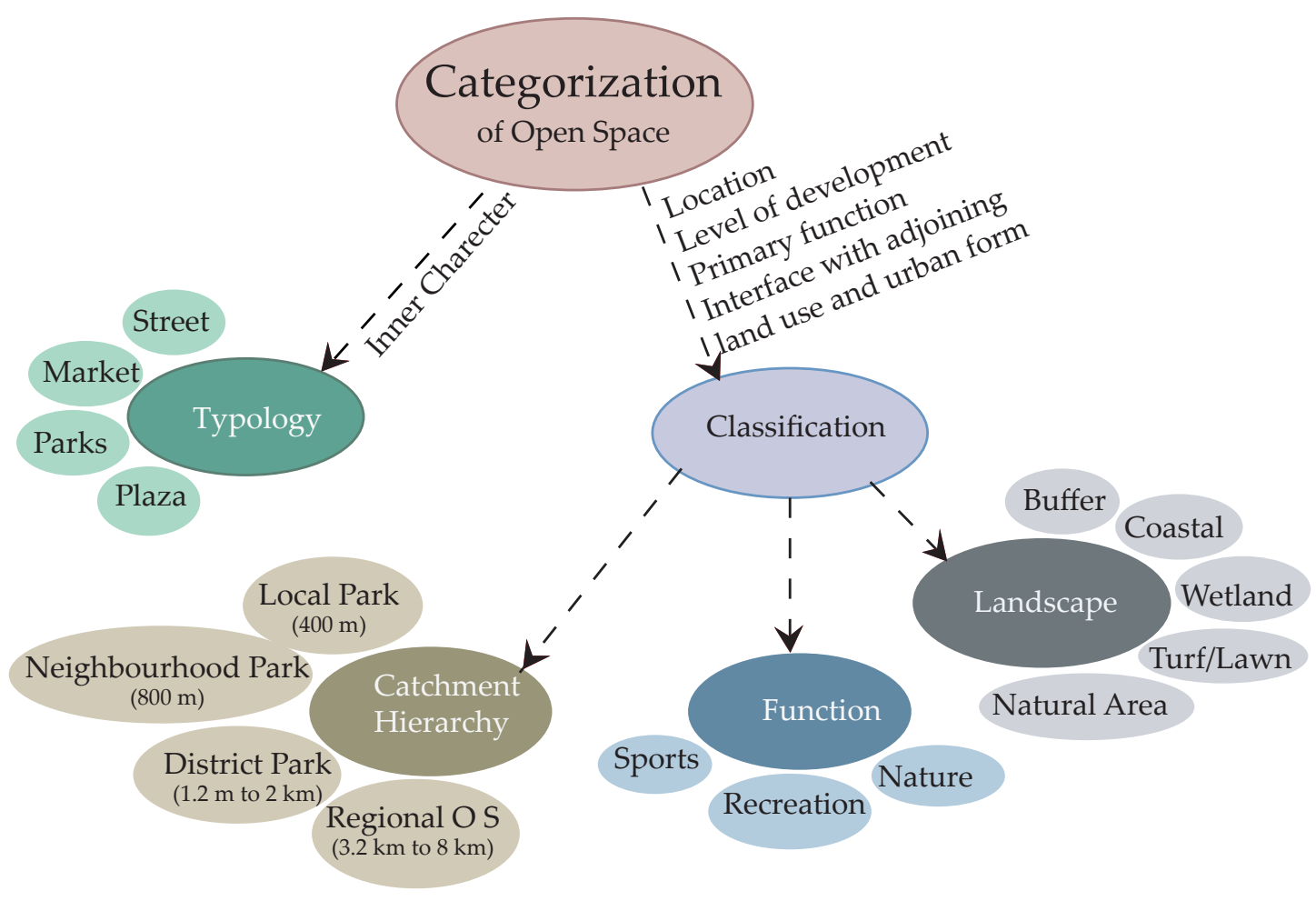

Figure 2. Categorization of open space derived from Appendix B.

\subsection{Catchment Hierarchy}

This term in some sources is simply so-called hierarchy. Hierarchy is basically determined by the geographical area being serviced (catchment), size, level of use and significance. Rutherford (2013), established four categories of catchment hierarchy. These are:

Local open space: Local open spaces (LOS) are usually small parklands that service the recreation needs of the immediate residential population.

Neighborhood open space: Neighborhood open space (NOS) serves as the recreational and social focus of a community. Residents are attracted by the variety of features and facilities and opportunities to socialize.

District open space: District open space (DOS) is principally designed to provide for organized formal sport. DOS will very likely include substantial recreation space and some nature space. DOS design and function should consider biodiversity principles and environmental management goals. DOS serves several neighborhoods with players and visitors traveling from surrounding districts.

Regional open space: Assist to preserve local biodiversity and natural area values.

\subsection{Landscape/Environmental Setting}

Each open space is assigned with a landscape/environmental classification that reflects their primary physical setting [34]. This is a landscape setting type classification, which proposed to assist with the differentiation of sites to specify the types of experiences for planning, management and marketing purposes. These are used where the setting type may not be evident from the functional classification. Landscape character is used to define desirable landscapes and/or vegetation [31].

Chittagong has seven types of open space, as described in Table 1. Among them city park and local park can be categorized as catchment type. Where neighborhood open space, district open space, and regional open space are missing. Figure 1 showed the catchment area of local parks in Chittagong in term of accessibility. Again, playground and sports centers can be defined as functional open space. In landscape category, Chittagong has coastal areas and natural areas, which will be discussed later. 


\section{Analyzing Existing Open Space in Chittagong}

This section will analyze the existing three types of park space to examine their structure, functional role, accessibility, and their respective probability to contribute to City's open space. Note that the playground and the sports complex will not be taken into consideration for this analysis; the planning proposals do not provide any guidelines for the existing playgrounds. Guidelines on the area surrounding the existing sports complex will be discussed.

\subsection{Amusement Parks and Zoological Parks}

Previously, the amusement parks of Chittagong were publicly accessible, now are privately-owned; which includes four amusement parks. Three amusement parks were suggested as proposed open space areas in the 1961 master plan for the City. Two of the amusement parks utilize their full land area, while the remaining two have land still available for potential use. In terms of the latter, this land may be considered as open space by providing accessibility and visibility to the City's residents. The percentage of land use related to open space of these two parks can be analyzed from data in the following table. An interesting fact related to these amusements parks is that they were all once public open space areas with free entry into their grounds. However, the trend of altering these existing open spaces into paid entry scenarios may be viewed as a retrograde measure as it has limited the access of large open space areas for the public - simply because many cannot afford to pay the ticket entry price. The percentage of land use associated with these park types can be analyzed as follows. Table 5 presents a number of open spaces related to this park category. However, there are two partially unused parks which can be used to help address the open space aspiration of the City: Foy's lake and the Zia Memorial Complex.

Table 5. The amusement parks and zoological parks in Chittagong.

\begin{tabular}{|c|c|c|c|c|c|c|}
\hline $\begin{array}{l}\text { Sl. } \\
\text { No }\end{array}$ & Name & $\begin{array}{c}\text { Surrounding } \\
\text { Land Use (DAP) }\end{array}$ & $\begin{array}{l}\text { Controlling } \\
\text { Authority }\end{array}$ & Area (Acre) & $\begin{array}{l}\text { Land Use } \\
\text { Percentage }\end{array}$ & $\begin{array}{c}\text { Unused } \\
\text { Area }\end{array}$ \\
\hline \multicolumn{7}{|c|}{ Areas recommended as open space in master plan } \\
\hline 01 & $\begin{array}{c}\text { Foy's Lake } \\
\text { Amusement park }\end{array}$ & Residential Area & $\mathrm{BR}$ & 85.32 & $12 \%$ & 650.68 \\
\hline 02 & $\begin{array}{l}\text { Karnaphuli } \\
\text { Children's Park }\end{array}$ & Residential Area & CCC & 8.74 & $100 \%$ & 0.00 \\
\hline 03 & Zia Children's Park & Recreational Area & $\mathrm{CCC}$ & 3.09 & $100 \%$ & 0.00 \\
\hline 04 & Zoo & Residential Area & CCC & 2.59 & $100 \%$ & 0.00 \\
\hline \multicolumn{7}{|c|}{ Areas not recommended as open space in master plan } \\
\hline 05 & $\begin{array}{l}\text { Zia memorial } \\
\text { Complex }\end{array}$ & Residential Area & $\mathrm{BB}$ & 14.07 & $48 \%$ & 9.68 \\
\hline 06 & Butterfly Park & Restricted Area & CDA & 3.89 & $100 \%$ & 0.00 \\
\hline \multicolumn{4}{|c|}{ Total } & 127.38 & \multicolumn{2}{|c|}{672.19} \\
\hline
\end{tabular}

\subsubsection{Foy's Lake}

Foy's lake is a constructed water body set in a hilly area of considerable natural beauty; which is located in the center of the Chittagong. The lake was constructed in 1924 to provide water for households and it is owned by the Bangladesh Railway. The area in which the lake is set was designated as a Regional Park in the 1961 Master Plan, and although it has ticketed entries at each lake end (there are two), the surrounding edges of the lake are occupied by slums and squatters which also prevent wider public access to the lake as an open space resource (Figure 3). To address this lack of access, as an initial step, Chittagong's 1995 Urban Development plan stated that no other development (i.e., non-recreational) will be permitted within the lake's surrounding area. 


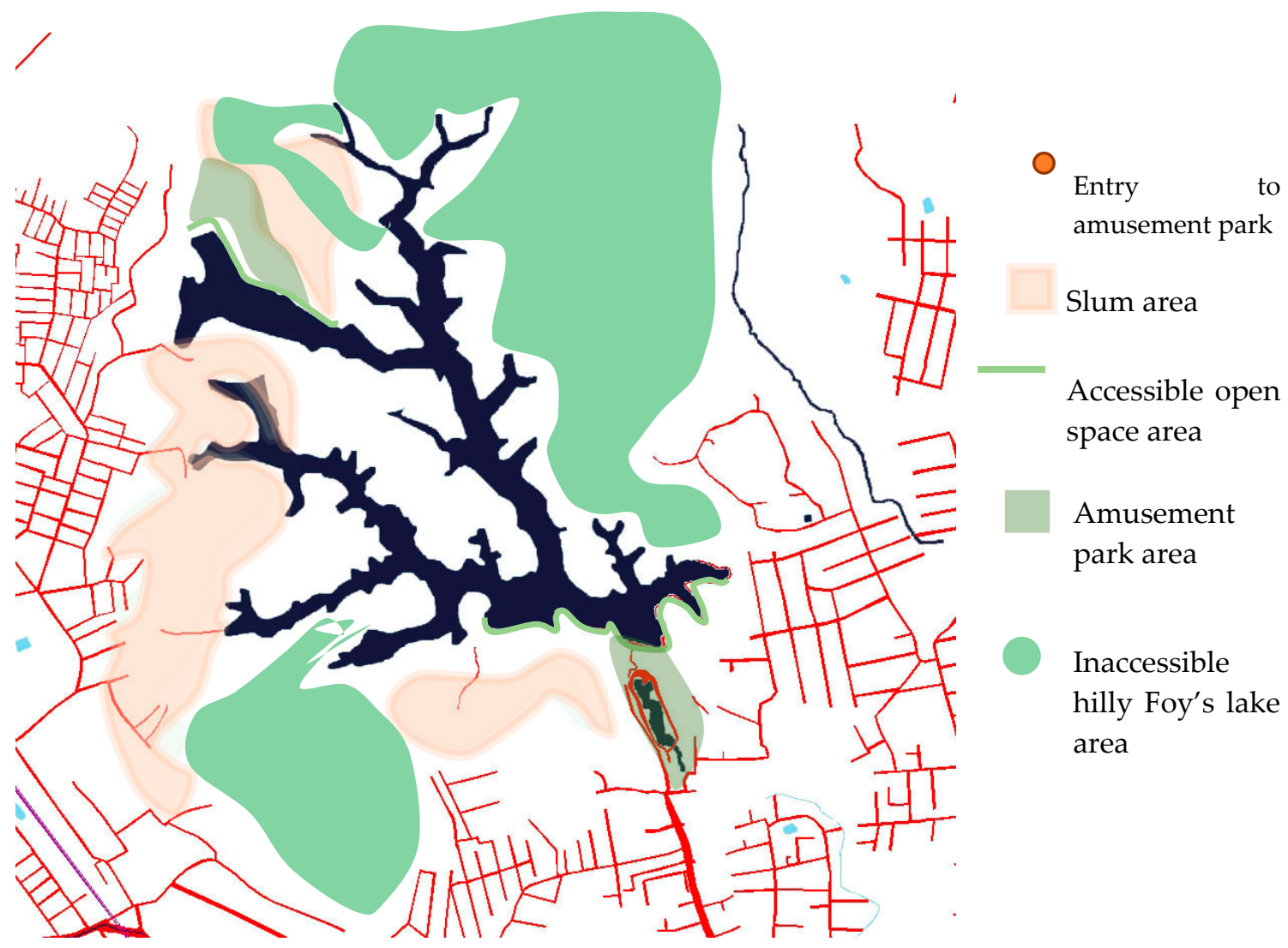

Figure 3. Foy's Lake Area.

Unfortunately, this recommendation does not truly help support one's access to the lake as the surrounding terrain is considered rather hilly and naturally prevents the public from accessing the lake's shores. However, its potential to contribute as an open space of the city is due to its large area; which equates to an area of 736 acres. Note that this lake is the largest open space area in the city, but because of a lack of accessibility, due to the hilly terrain, and that its approach/use is limited to $78 \%$, this water body is unused and considered inaccessible (Figure 3).

\subsubsection{Zia Memorial Complex}

This second partially unused open space area is historically important for the City because of its use as a radio tower; which was initially established in 1954. The site is currently owned by the Bangladesh Betar; the amusement park is leased to a private owner. Part of the grounds area is used as an amusement park, but a large portion of it is kept as unused space because of the boundary wall surrounding the site that restricts accessibility. A total $42 \%$ of the area is unused space (Figure 4 ). There is only one entry to the amusement park. 


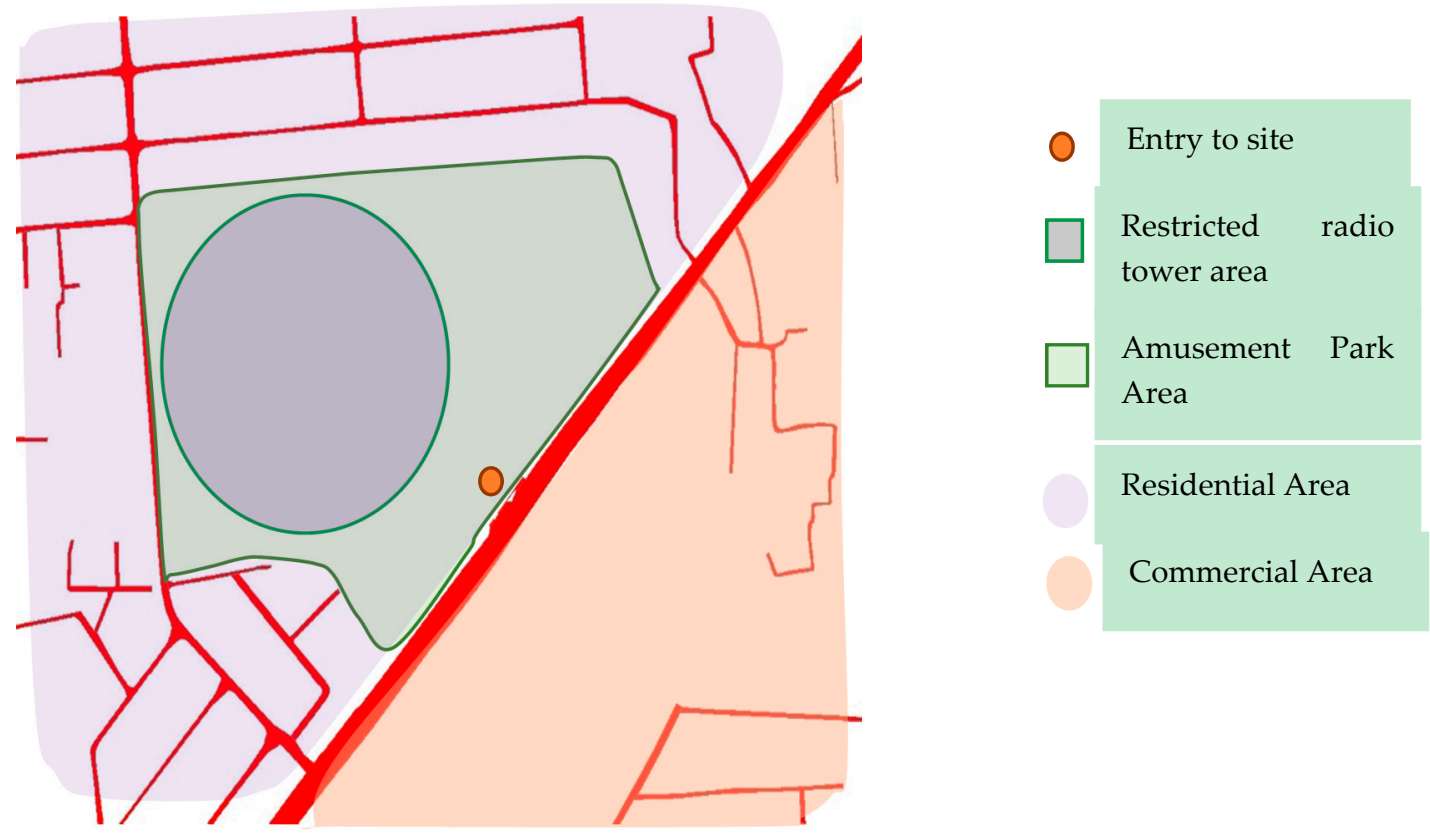

Figure 4. Zia Memorial Complex and radio station area.

\subsection{The City Parks}

Currently there are three city parks in Chittagong that provide open space for the City's residents. These parks are recommended official open space in master plans and are planned for conservation. Table 6 illustrates three city parks in Chittagong. These are as follows and a general description of each is provided below.

Table 6. City parks in Chittagong.

\begin{tabular}{ccccc}
\hline S1. No & Name & Surrounding Land Use (DAP) & Controlling Authority & Area (Acre) \\
\hline 01 & DC Hill Park & Residential Area & DC Office & 17.92 \\
02 & CRB Hill & Administrative and Recreational Area & BR & 10 \\
03 & Patenga Sea Beach & Commercial and Residential Area & CCC & 18.37 \\
\hline \multicolumn{7}{r}{} & Total & & 46.24 \\
\hline
\end{tabular}

\subsubsection{Hill Park}

This park earned its name from the official residence of the Deputy Commissioner (DC); his residential estate was located on the peak of the hill. There are vehicular roads on two sides of this triangular shape park and the remaining hilly side abutting the residential area is not connected (Figure 5). The area is controlled by a boundary wall and there is only a single entry/exit into/out of the site. The park area is 8.49 acres in size and the total site area is about 17.92 acres, with almost $50 \%$ of it unused by Chittagong's residents. 


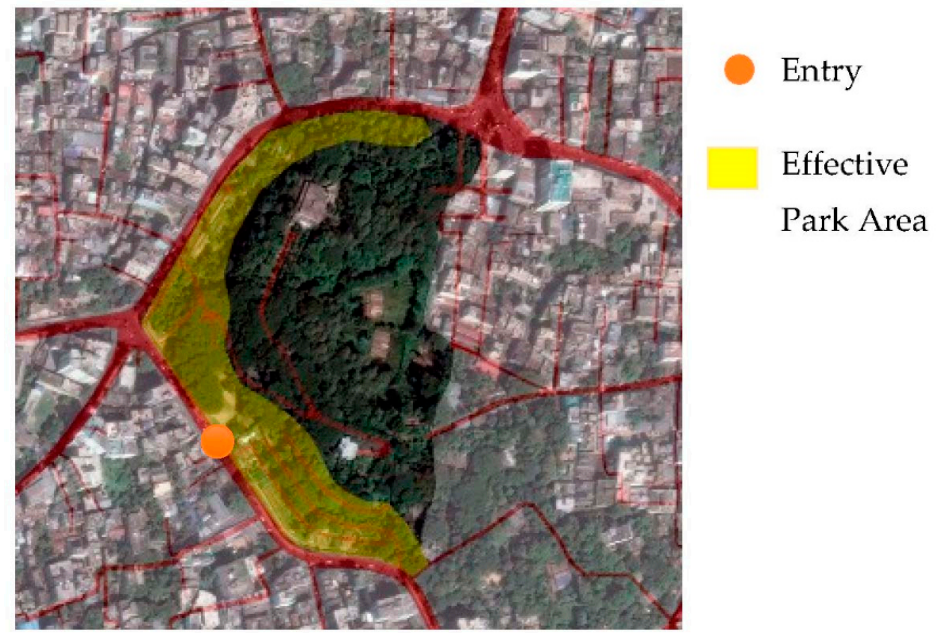

Figure 5. DC Hill area.

\subsubsection{Patenga Sea Beach}

Patenga Sea Beach is the most popular open space in Chittagong. Though the city itself is positioned beside the sea, this is the only official beach area provided by the City authority and officially utilized by its residents. This section of the beach contains an embankment along with a road that is almost $1.09 \mathrm{~km}$ in length. The total area of the beach amounts to 18.37 acres, with $50 \%$ of the area occupied by shops (Figure 6). It has only one public toilet including a shower facility; which is in very poor condition. As $50 \%$ of this natural space is occupied by shops, the openness of the beach is disrupted and can only be seen from the main road. In the potential use of this open space area it will be important to enhance the visibility of the sea and increase the beach area. Furthermore, the beach is connected to the main road by only one road, so to potentially improve the open space dimension of the city, it is important to increase the approach(es) from the main road to the beach. The area is maintained by CCC. Detailed area plan guidelines in this site are referred to as RO-01-01 "The existing beach shall be upgraded and two new sandy sites on the west, developed with public amenities such as rest rooms, souvenir shops, and a snack stand".

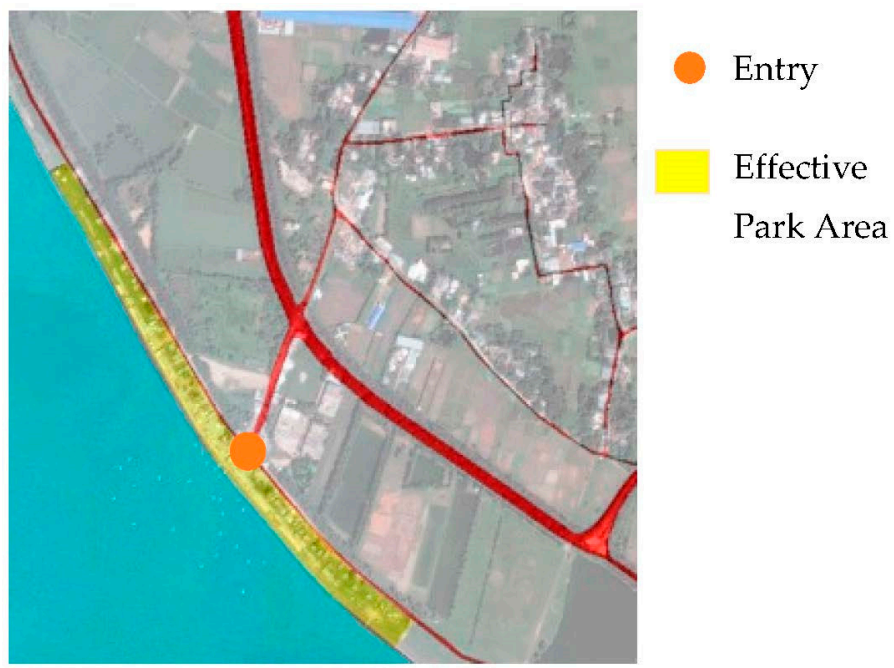

Figure 6. Patenga Beach area.

\subsubsection{Central Railway Building Hill}

The Central Railway Building (CRB) has 10 acres of land area that are located in the city and owned by the Railway Authority. This setting includes residential parcels and commercial buildings 
helping to serve as open space. This space is in a degraded state and due to a lack of proper lighting after dusk, this place is reported to be a haven for antisocial behavior. The park lacks pedestrian connectivity from the residential areas surrounding it, as the area is circled by large roads. The park area, however, does not have any other approach or connectivity from the road except for a scenic view point. So, this open space setting acts like an island surrounded by a high traffic road (Figure 7). The CRB is recommended as a recreational open space area in the Detail Area Plan of Chittagong.

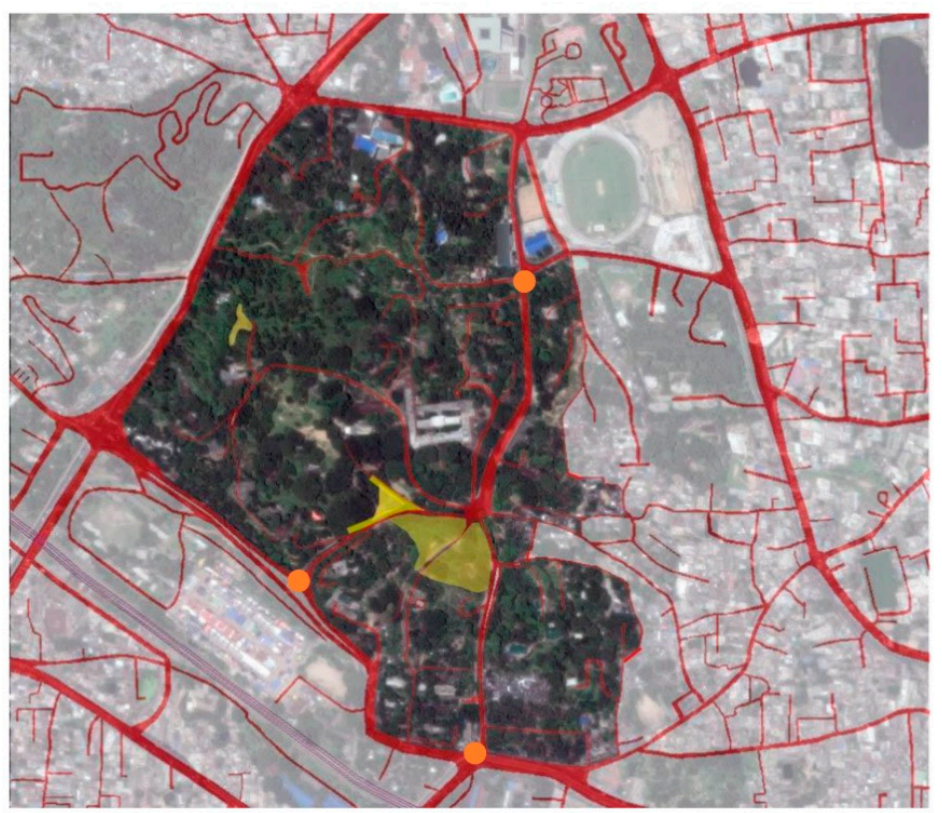

Entry

publicly

Accessible area

Figure 7. Central Railway Building (CRB area).

\subsection{Local Parks}

Additionally, larger municipal related land areas, such as local parks, are important to serve the neighborhood community. However, in Chittagong, there are only five local parks that can play this role illustrated in Table 7.

Table 7. Local parks in Chittagong.

\begin{tabular}{ccccc}
\hline No & Name & Surrounding Land Use (DAP) & Controlling Authority & Area (Acre) \\
\hline 01 & Biplob Uddayan & Commercial Area & CCC & 1.26 \\
02 & Laldeeghi & Commercial Area & CCC & 2.69 \\
03 & United Nation Park & Residential Area & CCC & 2.30 \\
04 & Halishahar I Block Park & Residential Area & NHA & 1.03 \\
05 & Halishahar H Block Park & Residential Area & NHA & 1.46 \\
& Total & & & 8.74 \\
\hline
\end{tabular}

From Table 7, the first three parks listed are surrounded by a boundary fence with only a single entry; which has restricted entry times. The remaining two parks are open at all times to the public. These local parks are publicly accessible green spaces, available free of cost and mainly used by the residents living in the catchment area [35]. Increasing the number of local parks in the city residential areas is suggested as a means to efficiently improve the open space situation for the city's neighborhood areas. For example, having greenspace within a 5-min walk of one's home is a strong indicator for one's health and quality of life [18]. So, it is necessary to increase the number of local parks accessible to residents. 


\section{Review of Planning Proposals in Chittagong}

What the above alludes to is that a coordinated effort and strategy for the improvement of the City's open space is needed. In the above section, the existing open spaces that have been analyzed are both officially and unofficially used as open spaces. This section aims to analyze the master plan proposals and to create an open space database of Chittagong. Hence, a series of planning proposal for Chittagong were prepared by the CDA which were arbitrarily selected for preservation for open spaces owned by government and nongovernment organizations and individuals. As briefly mentioned above, the authority was established in 1959 with the intent to ensure the planned and systematic development, improvement, and expansion of the city and certain areas of its vicinity. Its main objective was to ensure the planned and systematic growth of Chittagong. The CDA's main effort in this regard was the preparation of the City's Master Plan in 1961; which was upgraded in 1995. In 2015, the CDA prepared the Detailed Area Plan for the City; which now governs the development and open space requirements for Chittagong. A main feature of this document is the planning proposals embedded within it that are related to a series of open space issues the City has been facing for decades. The structure of the planning proposals can be viewed below.

- $\quad$ Master Plan 1961

- Master Plan 1995

- $\quad$ Structure Plan (1995-2015)

- Urban Development Plan (1995-2005)

- Long Term Development Strategy for Traffic and Transportation in Chittagong (1995-2015)

- Chittagong Storm water Drainage and Flood Control Master Plan (1995-2015)

- $\quad$ Detailed Area Plan (up to 2015)

\subsection{Master Plan 1961}

The 1961 Master Plan prepared by the CDA addressed a city area of 550 square kilometers. The plan stated that the open space problem is due to a lack of public parks, play fields, and small children's play areas; which, unfortunately, greatly simplified the issue. According to the plan, it identified a "grave deficiency of open space, particularly public parks and small areas suitable for use by children" as a major problem for Chittagong's residents [8]. And in this sense, the master plan found that only 88 acres of land of the City's total area were dedicated to parks and playgrounds. Hence, it recommended 26 different proposals to create 2935 acres of land for new parks and open space areas in the City (Figure 8). In Table 8, it can be seen that only four proposals recommended in the master plan were partially implemented. Among these four, three proposals have been also partially turned into an amusement park. The major problem for implementing the proposals or changed in land use proposals is that the majority of proposed lands are owned by other government and private organizations or individual land owners.

\subsection{Master Plan 1995 and Detailed Area Plan 2015}

The second master plan was prepared in 1995 and includes three tiers related to the City's development: Structural Plan, Urban Development Plan, Long Term Development Strategy for Traffic and Transportation in Chittagong (1995-2015), Chittagong Storm water Drainage and Flood Control Master Plan (1995-2015), and Detailed Area Plan. The Detailed Area Plan was prepared in 2015 and relates to the City's existing open space in context of the Urban Development Plan, a Storm Water Drainage Master Plan, and Transportation Master Plan. Each of these is supported by a number of proposed guidelines and policies that lead to the creation of open space in the City. The latest planning proposal named the Detail Area Plan segregate land use by splitting the whole city into twelve zones. The existing open space preservation and conservation is mentioned on each space by categorizing them as Leisure Recreation, Parks, and Open Spaces (RO), shown in Table 9. But there were no significant strategies in open space planning in the proposals. Another type of proposal 
can be taken under open space conservation, which is mentioned as Environmental Protection and Enhancement (En) and Cultural Heritage ( $\mathrm{CH}$ ). These guidelines are discussed below and individually they contribute to the City's total open space. The Detailed Area Plan for Chittagong, in 2015, recommended policies based on the 1995 master plan. Which, in terms of the 1995 plan, recommended the creation of a department named the 'Chittagong Parks and Recreation Department', whose intention is to work with the Chittagong City Corporation and liaison and the Planning Authority to acquire, design, and maintain the City's parks and open space area. The 1995 plan also proposed to develop a twenty-year plan for the implementation of a park and open space system; which the DAP refers to as the 'Chittagong Green Space Programme'. The DAP also recommended that all government organizations with suitable land enclosed and/or that accompany their related facilities shall be designed and maintained as public open space. Recommendations such as these can be taken into consideration when attempting to overcome the potential issue of land ownership or expropriation of land within the City's boundary. The ordinance, related to this expropriation of land, also suggests that the CCC may provide and maintain, within the Chittagong, open space as necessary for the convenience of the public and such spaces shall be grassed, hedged, planted, and designed to include amenities [4]. A number of additional proposals related to improving the City's open space situation are discussed below in Table 9.

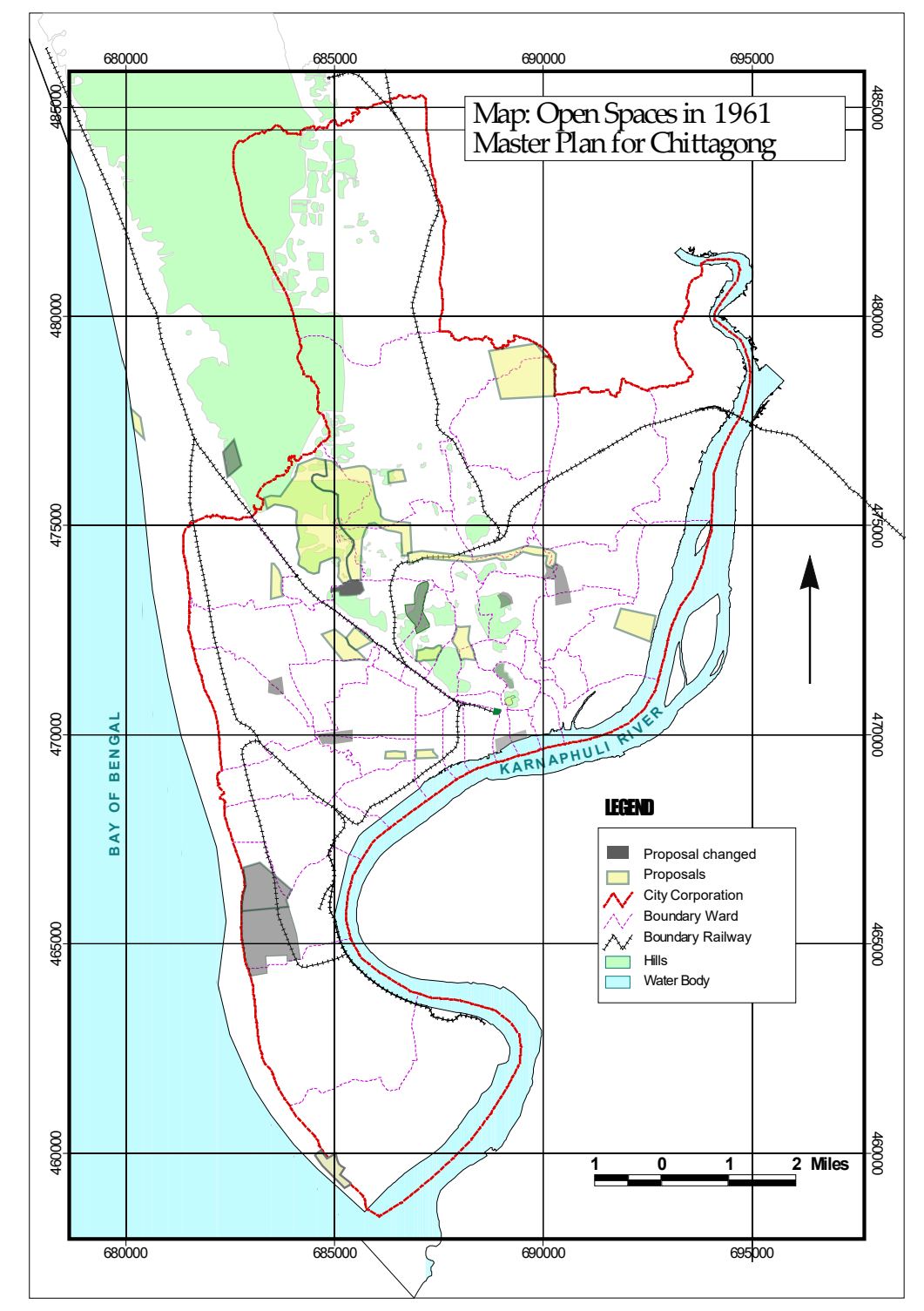

Figure 8. Proposals of open space 1961 master plan source: created by author. 
Table 8. The 1961 master plan proposals and the implementation status.

\begin{tabular}{ccc}
\hline & Proposals and Implementation Status & Area (Acre) \\
\hline & Land use changed: 12 & 998 (Total) \\
\hline 1 & Partially implemented: 04 & 867.37 (Total) \\
2 & Circuit House and Chittagong Stadium & 84 \\
3 & Agrabad & 29 \\
4 & Foy's lake Regional Park & 736 \\
\hline & Patenga Sea beach & 18.37 \\
\hline 1 & Not implemented: 10 & 935 (Total) \\
2 & Riverside Tank (Agrabad) & 25 \\
3 & Stadium and Central Eidgah Pahartali & 92 \\
4 & Railway Tank, Pahartali & 43 \\
5 & Botanical and zoological Gardens & 354 \\
6 & Batali hill & 53 \\
7 & Bayazid Bostami Shrine Nasirabad & 17 \\
8 & Regional Park, East of Hathazari road & 99 \\
9 & Park way along Chaktai Khal & 115 \\
10 & Foujderhat Sea Beach (outside city corporation area) & 50 (estimated) \\
\hline
\end{tabular}

Table 9. The 1995 master plan proposal and implementation status.

\begin{tabular}{|c|c|c|}
\hline Proposals & Existing Status & Area \\
\hline \multicolumn{3}{|c|}{ Structure Plan } \\
\hline $\begin{array}{l}\text { Creation of a landscape park } \\
\text { adjacent to Jumiatul Falah Mosque }\end{array}$ & $\begin{array}{l}\text { A field area for stockpiling construction material for ongoing } \\
\text { development road works. Area is connected by footpaths on } \\
\text { the adjacent roads }\end{array}$ & 7.6 \\
\hline $\begin{array}{l}\text { Further development of the } \\
\text { zoological and botanical garden at } \\
\text { Foy's lake }\end{array}$ & $\begin{array}{l}\text { A zoo and amusement park. Most of the park remains } \\
\text { unused due to inaccessibility }\end{array}$ & 736 \\
\hline $\begin{array}{l}\text { CRB (Central Railway Building) } \\
\text { Area }\end{array}$ & $\begin{array}{l}\text { Public open space but is currently in a degraded condition } \\
\text { and, after dusk, turns into a place for antisocial activities }\end{array}$ & 10 \\
\hline \multicolumn{3}{|c|}{ Structure Plan and Urban Development Plan } \\
\hline Batali Hill & $\begin{array}{l}\text { In very poor condition, weak connection to the City and, } \\
\text { particularly, its surrounding areas. Insufficient Landscape } \\
\text { elements. }\end{array}$ & 53 \\
\hline \multicolumn{3}{|l|}{ Urban Development Plan } \\
\hline Northern Hills & $\begin{array}{l}\text { Hilly area which is not accessible. Excavation of the hill } \\
\text { occurs in this area. The area is close to the City's industrial } \\
\text { zone which are occupied by informal settlements. }\end{array}$ & 200 \\
\hline \multicolumn{3}{|l|}{ Detailed Area Plan } \\
\hline Debar par Lake front development & $\begin{array}{l}\text { Flooded by tidal water and occupied by informal } \\
\text { settlements. }\end{array}$ & 22 \\
\hline $\begin{array}{l}\text { Karnaphuli River Front } \\
\text { Development project }\end{array}$ & $\begin{array}{l}\text { This is submerged land that is not connected to the } \\
\text { surrounding areas of Western bank of the river stretches } \\
\text { from Kalurghat bridge to Shah Amanat bridge. }\end{array}$ & 30 \\
\hline
\end{tabular}

\subsection{Description of Sites Proposed in Planning Proposals}

\subsubsection{Northern Hills (Bhatiary)}

The contents in the above discussion suggest a range of considerations that, if acted upon, may help alleviate some of Chittagong's decreasing and lack of open space areas for the City's residents. In particular, the Urban Development Plan recommends that the northern part of Foy's Lake needs to be designated as a regional open space. This recommendation is made because of the hills, forests, 
and central lake inside its boundary easily attracts visitors [10]. Additionally, passive relaxation (e.g., sitting) and fishing facilities are provided in this space; which help allow for a range of uses in this setting. The site is ideal as a large recreational area as it has an estimated area of 200 acres. Part of the site is inside the boundary of CCC area. However, the development pressure on this land is high, as it is only $20 \mathrm{~km}$ away from the city. Yet, the area is 'secure' due to its proximity to a Military installation and the need for this camp to maintain a buffer around its facility.

\subsubsection{Batali Hill}

This hill is the second largest open space in Chittagong and spreads over 53 acres of land. The hill is about $90 \mathrm{~m}$ in height and faces threats of erosion and landslides due to illegal excavation of the hill. This excavation was made to collect soil for the brick industry and to perform development works like housing. Unfortunately, due to the hill's slope, most of the area is not accessible to the City's residents. The hill is connected to a vehicular road and two series of stairs that provide access to the hill. In the 1961 Master Plan, this hill is marked as special planning zone which is to be preserved as botanical garden for Chittagong, as the City does not current have such a garden. The site is partially restricted by the private residence of Government officials (e.g., the Bangladesh Police and Public Works Department).

\subsubsection{Waterfronts}

There are a number of waterfront proposals embedded within the City's various plans. For ease of discussion these have been organized, below, into subsections in this paper.

i. Sea front (Outer ring road or new Embankment road): According to the Transportation Master Plan of Chittagong, the Chittagong Development Authority is constructing one section of the outer ring road with an embankment on the seaside of this road. The road extends from Potenga sea beach through to Dhaka Trank Road. This embankment has the potential to provide an opportunity to create a pedestrian friendly walkway adjacent to the embankment $(10 \mathrm{~m}$ or more width). This ring road will be connected to the City by feeder roads that will open views to the sea by the city dwellers and include a pedestrian facility-like footpath.

ii. Karnaphuli River Front: The next phase of the outer ring road proposal is to build an embankment on the west bank of the Karnaphuli River. Simultaneously, the opportunity exists to develop the adjacent riverfront for creation of open space. According to DAP, from the Shah Amanat Bridge to the Karnaphuli Bridge, a riverfront project was suggested to be developed in the west bank of the river. The area, however, as previously mentioned, needs to be protected from urban development. And although the DAP has demarcated for protection the area up to the Shah Amanat bridge; the importance of the Chaktai creek area also needs to be included in this measure. The river frontage is the old part of the Chittagong city area; which has been developed on the side of Chaktai Creek. This river side area is engaged with Navy- and Port-related construction activity along the south of the City. As a result, this activity restricts accessibility of public.

iii. Ponds: Chittagong has number of large ponds that are occupied by the City's slums. These slums not only restrict the accessibility of use to the adjacent water's edge but also constrain the visibility of the ponds. In the 1961 Master Plan, the Riverside tank in Agrabad and the Railway Tank in Pahartali were recommended to be preserved as open space, and more recently, the DAP proposed development of these ponds as flood storage ponds and as open space.

iv. A green belt and walkway on both sides of the existing creeks: The DAP for Chittagong recommended the creation of a network of linear open spaces by linking together and making better use of the City's river valleys and natural creeks (e.g., Chaktai creek). In support of these recommendations the greening of the edge of the creeks should also be considered. This open 
space recommendation may also act as a linear green space and walkway that can connect the open spaces scattered around the city [36].

\subsubsection{Cultural Hub}

The Chittagong Shaheed Minar is a built feature of national importance and is located in the cultural enclave area proposed in 1961 Master Plan. The 0.12-acre complex is designed to commemorate the City's devotees that fought to regain the Bengali Language as the national language (Yellow area in Figure 9). This area is located adjacent to the City's secondary major road; which has a small space in front of it, this memorial is to accommodate people that come here on a variety of important national and local celebratory days, such as Independence Day and Mother Language Day. Individual people with or without family, government, or private and social organizations come here to show their respect to the people that have contributed to the development of Chittagong and the nation.

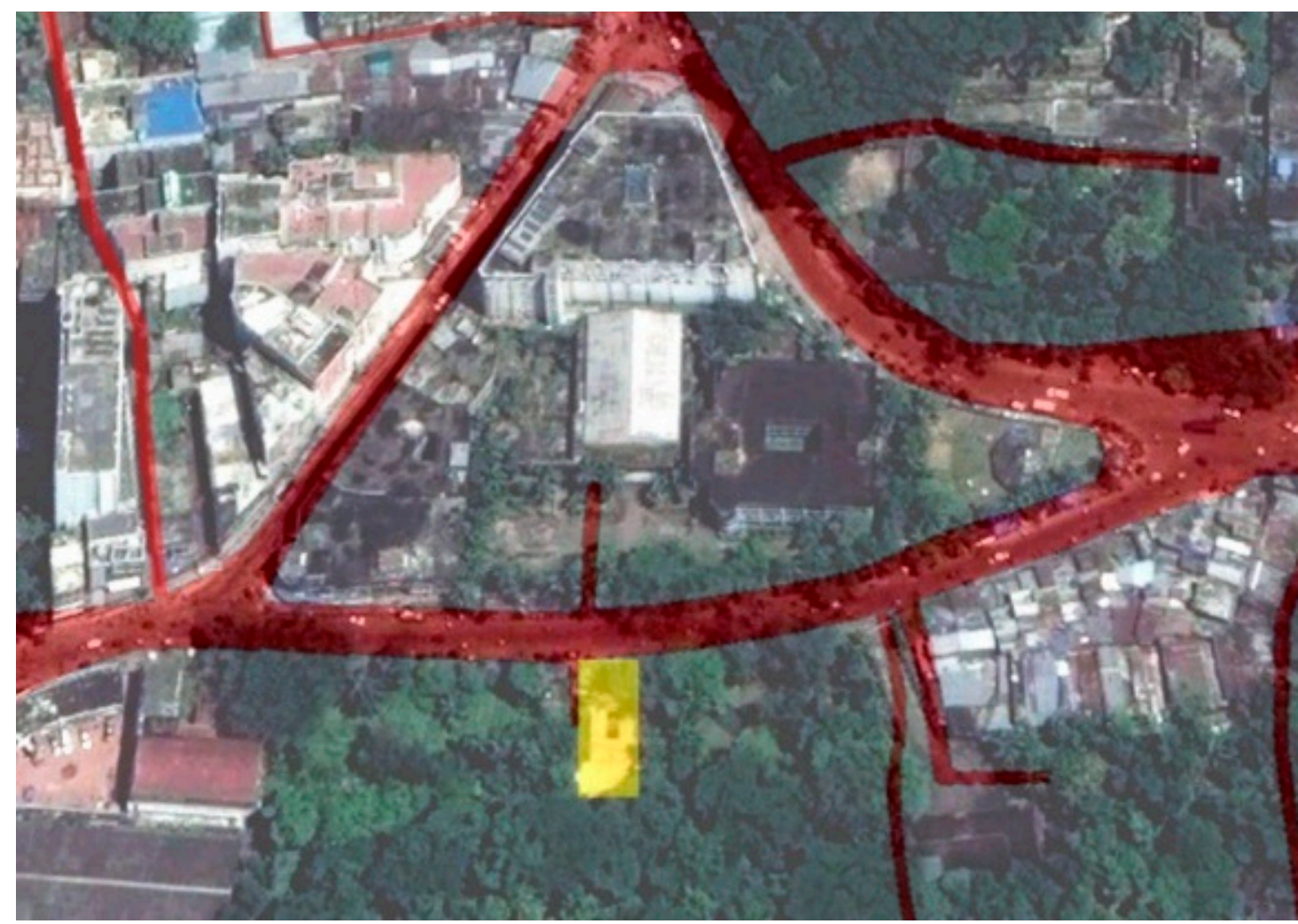

Figure 9. Cultural enclave site.

\subsubsection{Rail-Line Corridor}

A prominent feature of Chittagong City is its green corridor, which can be found running along the sides of the Rail line. To improve its open space ratio the DAP recommended greening and creating usable recreational space on the sides of this unused railway track. The DAP also has the intention that this linear space can act as green corridor for the city, potentially linking the City's various urban areas together. As a result, this green corridor can connect the City's other open space areas such as the CRB, Batali Hill, A K Khan Hill, Jorr Deghi, and Belaur Deghi (Figure 10). Thus, an interconnected network of green spaces can also be achieved that can connect all existing major parks, nodes, and open space areas. Installing this interconnected network can link together the City's road reserves, utilities reserves, ponds and drainage reserves, railway reserves, scenic roads, and scenic easements [37]. However, the continuation of existing green space is hindered by the railway's workshop and the City's slums that occupy the sides of the rail line. The following table is a list of open space planning 
proposals at different levels. The table shows that the cumulative area of proposals can improve the amount of open space if initiative is implemented.

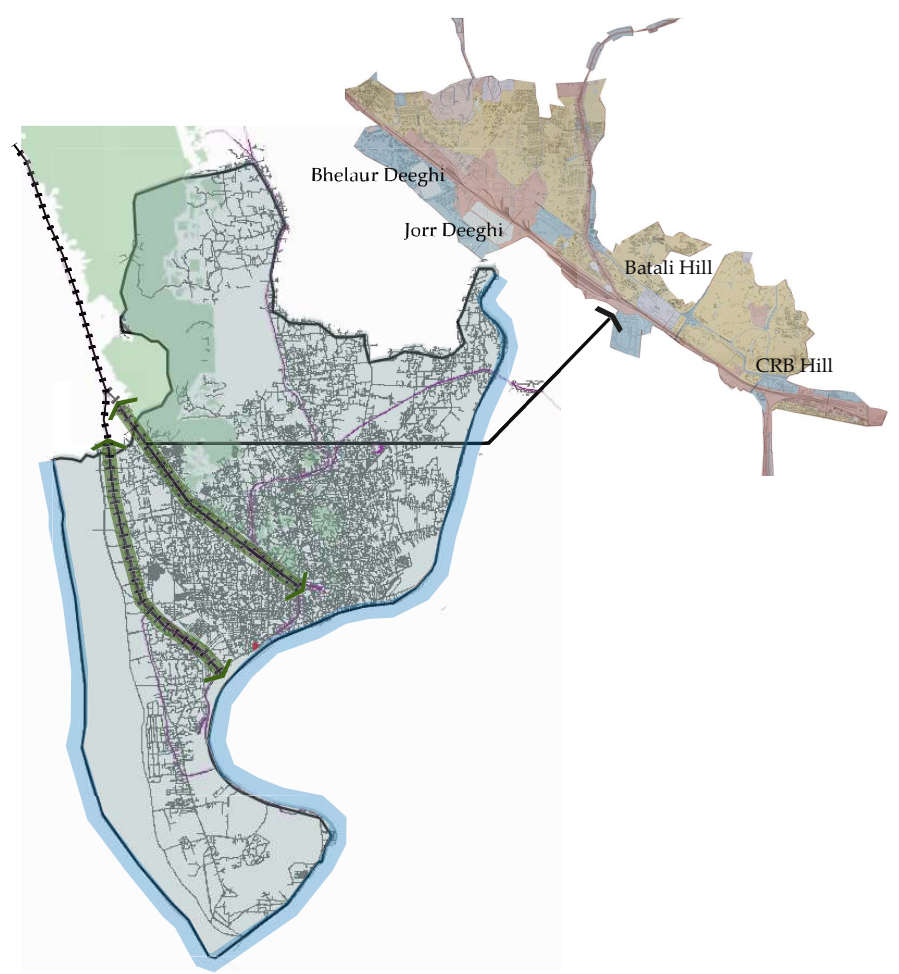

Figure 10. Rail-line corridor.

According to the 1961 Master Plan, 1995 Master Plan, and DAP guidelines, Chittagong still has the opportunity to create open space by implementing the policies and guidelines previously mentioned. The total open space according to the current planning proposals can still provide 1.67 square meters of open space per capita. Though the open space planning proposals can increase the total open space, it is important to understand why and how these proposals eventually failed to reach the aspiration of the total open space in Chittagong. The problems and weakness of the Master plans need to be identified to draw a successful open space proposal. The above discussion shows that the Chittagong Master Plan only provides guideline on open space that can be mostly categorized as City parks. While the existing open space (Table 1) shows that Chittagong has shortfall of local parks. Again, according to classification of open space, Chittagong lacks neighborhood open space and linear open space. District open space and regional open space can be considered while the planning involves the Chittagong District as a whole. Local and neighborhood parks provide accessible open space for frequent visits and need to be located at least in walking distance $(400 \mathrm{~m})$ of a neighborhood.

\section{Conclusions}

In conclusion, this paper examined the open space scenario in Chittagong and demonstrates that by implementing the City's master plan proposals gains can be made relative to the City's existing open space situation. However, only implementing the City's open space plans will result in a quantitative delivery of land. The desired outcome of achieving net gains will need to be assisted by also preserving the open spaces demarcated in the master plan that are under threat by development. Though the proposals are made on private and different government organizations' land and the steps recommended in the DAP, a time scale program can be taken for the implementation of these proposals.

The paper found that by simply adhering to the proposed implementation guidelines included in the City's various master plans, the open space per capita in Chittagong can be increased from $0.18 \mathrm{~m}^{2}$ 
to $1.67 \mathrm{~m}^{2}$. It is understood that this standard is far below those stated by the WHO and that of the country of Bangladesh. However, as Chittagong is bounded by the sea and river to its west and east, respectively, the City can develop more riverfront open space by increasing accessibility, connectivity, and visibility of the waterfront to the City's dwellers. Hence, more open space can be found and realized by simply looking at the potential of spaces with and adjacent to the City. Lastly, it is suggested that, although the master plan suggestions will increase the ratio of open space in Chittagong, it will still be important to develop distinct guidelines related to open space conservation, land acquisition, and government funding of such open space works. Otherwise, the open space proposals found in the City's various master plans will continue to fail to meet the Chittagong's open space needs and not be realized. The article tried to show the proposals on open space in a table (Table 10). It is recommended to plan the open space of Chittagong more specifically, such as hierarchy type by mentioning area and minimum distance and also by environmental type, which has been found in the literature review. For further direction, it needs to follow the design criteria and process to achieve its goal.

Table 10. Combined list of existing open space and recommended open spaces in master plan.

\begin{tabular}{|c|c|c|c|}
\hline & Name & Source/Details & Area (Acre) \\
\hline \multirow{6}{*}{$\begin{array}{l}\text { Regional Park: Botanical } \\
\text { and Zoological Garden }\end{array}$} & Northern Hill & Urban Development Park & 200 \\
\hline & Batali Hill & $\begin{array}{l}\text { Master plan } 1961 \text { and } \\
\text { Detailed Area Plan } 2015\end{array}$ & 53 \\
\hline & Foy's Lake (without & Structure plan 1995 and & \\
\hline & amusement park area) & Detailed Area Plan 2015 & 646 \\
\hline & Butterfly Park & Existing open space & 3.89 \\
\hline & Zoo & Existing open space & 2.59 \\
\hline \multirow{3}{*}{ City Park } & CRB & Structure plan 1995 & 10 \\
\hline & Batali Hill & Master Plan 1961 & 53 \\
\hline & DC Hill Park & Existing open space & 17.92 \\
\hline \multirow{4}{*}{ Waterfront } & Marine drive and beach & CDA project & 50 \\
\hline & Patenga Beach & $1.5 \mathrm{~km} \times 7 \mathrm{~m}$ & 2.6 \\
\hline & Karnaphuli river front & Detail Area Plan & 25 \\
\hline & Foujderhat Beach & Master Plan 1961 & 3.1 \\
\hline \multirow{2}{*}{ Cemetery and Memorial } & Central Shaheed Minar & $\begin{array}{l}\text { Proposal of extension in } \\
\text { existing area }\end{array}$ & 1 \\
\hline & War Cemetery & Existing open space & 5.24 \\
\hline \multirow{2}{*}{ Religious Open Space } & Jumiatul Falah Mosque & Structure Plan 1995 & 7.6 \\
\hline & $\begin{array}{c}\text { field } \\
\text { Bayazid Bostami Shrine }\end{array}$ & Master Plan 1961 & $\begin{array}{l}\text { (excluding mosque) } \\
17\end{array}$ \\
\hline \multirow{2}{*}{ Ponds } & Agrabad Deba & $\begin{array}{c}\text { Master Plan } 1961 \\
\text { Detailed area Plan } 2015\end{array}$ & 25 \\
\hline & $\begin{array}{c}\text { Jorr Dighi and Bhelaur } \\
\text { Dighi }\end{array}$ & Master Plan 1961 & 43 \\
\hline \multirow[t]{2}{*}{ Park way along creeks } & $\begin{array}{c}\text { Chaktai Khal } \\
(5.1 \mathrm{~km} \times 3 \mathrm{~m} \times 2)\end{array}$ & Master Plan 1961 and DAP & 7.56 \\
\hline & $\begin{array}{c}\text { Moheshkhali } \\
\text { Khal }(4.9 \mathrm{~km} \times 3 \mathrm{~m} \times 2)\end{array}$ & DAP & 7.26 \\
\hline Railway Corridor & $\begin{array}{l}\text { Greening on both side of } \\
\text { unused rail line }\end{array}$ & DAP & 200 \\
\hline Play ground & Total 64 Playgrounds & Existing open space & 106 \\
\hline \multirow[t]{2}{*}{ Stadium } & Total number: 02 & & 35.5 \\
\hline & Total & & 1700.16 \\
\hline
\end{tabular}

The paper has tried to uphold the possibility to increase open space in Chittagong, mentioning the recommendation of Master Plans and the respective guidelines. The first master plan failed to preserve twenty-six proposals for lack of preservation and conservation guidelines. The 1995 Master Plan and the Detailed Area plan have provided more detail preservation and conservation proposal; 
which, if followed by the planning body, can help reach the goal of increasing open space. A planned approach to the increase of open space in terms of typology and specified area for each typology will be necessary for residents who have access to open space and can be defined by catchment area. The alarming situation of losing open space that has been predicted can be overcome by documenting the segregated planning proposals.

Author Contributions: Conceptualization, M.J. and B.B.B.; Methodology, B.B.B.; Software, M.J.; Validation, M.J. and B.B.B.; Formal Analysis, M.J.; Investigation, M.J.; Resources, M.J. and B.B.B.; Data Curation, M.J.; Writing-Original Draft Preparation, M.J.; Writing-Review \& Editing, B.B.B.; Visualization, M.J.; Supervision, B.B.B.; Project Administration, B.B.B.; Funding Acquisition, N/A.

Funding: This research received no funding.

Acknowledgments: I would like to give my sincere gratitude to my supervisor Beau B. Beza for his guidance in research and careful revision of my writing of this report. I also am thankful to my co-supervisor David Jones who gave me the opportunity to pursue this research in the School of Architecture and Build Environment, Deakin University. The supporting material from Beza and Jones helped my research develop in the appropriate direction. I would also like to express my gratitude to the Planning Department of Chittagong Development Authority (CDA) for proving me the necessary maps and data for my research.

Conflicts of Interest: The authors declare no conflicts of interest.

\section{Appendix A}

Provision and Requirement of Community Facilities, 2000 in Kuala Lumpur [38]

\begin{tabular}{cccccc}
\hline Type & $\begin{array}{c}\text { No. of Unit per } \\
\mathbf{1 0 , 0 0 0} \text { Population }\end{array}$ & $\begin{array}{c}\text { Land Area } \\
\text { per 10,000 } \\
\text { Population } \\
\text { (Hectare) }\end{array}$ & $\begin{array}{c}\text { Minimum } \\
\text { Land Area } \\
\text { per Unit } \\
\text { (Hectare) }\end{array}$ & $\begin{array}{c}\text { Standard Area } \\
\text { (Hectare) } \\
\text { per Population }\end{array}$ & $\begin{array}{c}\text { Standard } \\
\text { Area } \\
\text { per Person }\end{array}$ \\
\hline $\begin{array}{c}\text { District Park } \\
\text { Neighborhood }\end{array}$ & 0.05 & 2.00 & 40.00 & $40.0 \mathrm{ha} / 20,0000$ & $2 \mathrm{~m}^{2}$ \\
Park & 0.20 & 2.00 & 10.0 & $10.0 \mathrm{ha} / 50,000$ & $2 \mathrm{~m}^{2}$ \\
Local Park & 0.50 & 1.00 & 2.00 & $2.00 \mathrm{ha} / 20,000$ & $1 \mathrm{~m}^{2}$ \\
$\begin{array}{c}\text { Local Play Area } \\
\text { Sports Complex }\end{array}$ & 2.00 & 1.00 & 0.50 & $0.50 \mathrm{ha} / 5000$ & $1 \mathrm{~m}^{2}$ \\
Total & 0.20 & 0.50 & 2.50 & $2.50 \mathrm{ha} / 50,000$ & $0.5 \mathrm{~m}^{2}$ \\
\hline
\end{tabular}

Source: Kuala Lumpur Structural Plan 2020.

\section{Appendix B}

Typologies of Open space in Australia

\begin{tabular}{|c|c|c|c|c|}
\hline $\begin{array}{l}\text { Western Australia } \\
\text { Rutherford (2012) }\end{array}$ & & PLA (2013) & & $\begin{array}{l}\text { South Australia } \\
\text { (City of Marion) }\end{array}$ \\
\hline Recreation space & Local Open Space & 0.5 ha & $1500 \mathrm{~m}-300 \mathrm{~m}$ & Turf/lawn \\
\hline Sport spaces & Neighborhood open space & 0.75 ha to 2 ha & $400 \mathrm{~m}$ & Watercourse \\
\hline \multirow{8}{*}{ Nature space } & Sub-District open space & $5-6$ ha & & Natural area \\
\hline & District open space & Up to 10 ha & $\begin{array}{c}6 \text { neighborhood/ } \\
15,000-25,000 \text { people }\end{array}$ & Undeveloped area \\
\hline & Township & Up to 10 ha & & Wetland \\
\hline & Municipal & Min 3 ha & at $2 \mathrm{~km}$ from locality & Drainage/stormwater \\
\hline & Regional & 10-30 ha & - & Buffer \\
\hline & \multirow{3}{*}{ State } & \multirow{3}{*}{ - } & \multirow{3}{*}{-} & Hard surface \\
\hline & & & & Coastal \\
\hline & & & & Unclassified \\
\hline
\end{tabular}




\begin{tabular}{|c|c|c|c|}
\hline $\begin{array}{l}\text { City of London Open Spaces Audit } \\
2013 .\end{array}$ & & London Plan & \\
\hline Parks and Gardens & Linear Open Spaces & Variable & Wherever Feasible \\
\hline Natural and seminatural greenspaces & Pocket parks & Under 1 acre (approx.) & Less than $400 \mathrm{~m}$ \\
\hline Local Green corridors & $\begin{array}{l}\text { Small open spaces } \\
\text { Gardens }\end{array}$ & 1 to 5 acre (approx.) & Less than $400 \mathrm{~m}$ \\
\hline Outdoor Sports Facilities & District/major parks & 50 to 150 acre (approx.) & $1.2 \mathrm{~km}$ \\
\hline Amenity Greenspace & Metropolitan parks: & $\begin{array}{l}150 \text { to } 1000 \text { acre } \\
\text { (approx.) }\end{array}$ & $3.2 \mathrm{~km}$ \\
\hline $\begin{array}{c}\text { Provision for children and young people } \\
\text { Cemeteries and churchyards } \\
\text { Primary civic spaces } \\
\text { Secondary civic spaces } \\
\text { Sites awaiting development }\end{array}$ & Regional parks & $\begin{array}{l}\text { Over } 1000 \text { acre } \\
\text { (approx.) }\end{array}$ & 3.2 to $8 \mathrm{~km}$ \\
\hline
\end{tabular}

Typology of open space proposed in Dhaka (Bangladesh)

\begin{tabular}{cccc}
\hline Dhaka Structural Plan (2016) & \multicolumn{3}{c}{ RAJUK (2016) } \\
\hline Park & Metropolitan Park & $150+$ acres & 3200-4800 m (approx.) \\
\hline Playground and sports facility & District Park & $50-75$ acres & 1200 m (approx.) \\
\hline Urban Development open space & Local Park & $5-10$ acres & 400 m (approx.) \\
\hline Functional Open space & 'Mini' Park & under 2 acres & less than 400 m (approx.) \\
\hline $\begin{array}{c}\text { Street scape, trails, and buffer } \\
\text { Urban forest/natural park }\end{array}$ & District Park & $50-75$ acres & 1200 m (approx.) \\
\hline
\end{tabular}

\section{References}

1. World Health Organization (WHO). Health Indicators of sustaiable cities. In Proceedings of the United Nations Conference on Sustainable Development, Rio de Janeiro, Brazil, 20-22 June 2012.

2. Kuchelmeister, G. Urban Forestry in the Asia-Pacific Region: Status and Prospects; Food and Agriculture Department (FAO): Rome, Italy, 1998.

3. World Health Organization (WHO). Urban Green Spaces: A Brief for Action; World Health Organization: Copenhagen, Denmark, 2017.

4. Chittagong City Corporation (CCC). The Chittagong City Corporation Ordinance 1982; Ordinance No. XXXV of 1982; Government of Peoples Republic of Bangladesh: Dhaka, Bangladesh, 1982.

5. Veal, A.J. FIT for the purpose? Open space planning standards in Britain. Policy Res. Tour. Leis. Events 2012, 3, 375-379. [CrossRef]

6. Elessawy, F. The Boom: Population and Urban Growth of Dubai City. Horizons Hum. Soc. Sci. 2017, 2, $26-41$. [CrossRef]

7. Chisty, K.U. Landslide in Chittagong City: A Perspective on Hill Cutting. J. Bangladesh Inst. Plan. 2014, 7, 1-17.

8. Hassan, M.N. A Study on Present Status and Potential Locations Open Spaces in the Chittagong City Corporation Area; Bangladesh University of Engineering and Technology: Dhaka, Bangladesh, 2008.

9. Hosssain, Z. Open Spaces and Water Bodies in Cities. In Proceedings of the Environmental Workers Training Workshop, Forum of Planned Chittagong, Chittagong, Bangladesh, 17-20 April 2002.

10. Chittagong Development Authority (CDA). Detailed Are Plan for Chittagong Metropolitan Master Plan; Ministry of Housing and Public Works (MoHPW), Ed.; Government Press: Dhaka, Bangladesh, 2015.

11. Bangladesh Government. Private Housing Land Development Rule; Ministry of Housing and Public Works (MoHPW), Ed.; Bangladesh Government: Dhaka, Bangladesh, 2004.

12. Yin, R.K. Case Study Research: Design and Methods, 4th, ed.; Sage Publications: Los Angeles, CA, USA, 2003.

13. Gould, E.R.L. Park Areas and Open Spaces in Cities. Am. Stat. Assoc. 1888, 1, 49-61. [CrossRef] 
14. City of Sydney. Open Space, Sports and Recreation Needs Study 2016; City of Sydney: Sydney, Australia, 2016.

15. Spencer, A.; Gill, J.; Schmahmann, L. Urban or suburban? Examining the density of Australian cities in a global context. In Proceedings of the State of Australian Cities Conference 2015, Gold Coast, Australia, 9-11 December 2015.

16. Theobald, W. A History of Recreation Resource Planning: The origin of Space Standards. Leis. Stud. 1984, 3, 189-200. [CrossRef]

17. Parks and Leisure Australia (PLA). Open Space Planning and Design Guide; Park and Leisure Australia: Victoria, Australia, 2013.

18. Greenspace Scotland; Scottish Natural Heritage. Developing Open Space Standards: Guidance and Framework; Scottish Government: Edinburgh, UK, 2013.

19. Bell, S.; Hamilton, V.; Montarzino, A.; Rothnie, H.; Travlou, P.; Alves, S. Greenspace Scotland Research Report; Greenspace Scotland: Stirling, UK, 2008.

20. Veal, A.J. Open Space Planning Standards in Australia: In Search of Origins. Aust. Plan. 2013, 3, $224-232$. [CrossRef]

21. Gungor, B.S.; Ozanguc, K.C. Functional Use Change in Green Spaces: A Case Study of Kirklareli Province. In Proceedings of the IOP Conference Series: Material Science and Engineering, Prague, Czech Republic, 12-16 June 2017.

22. UN-Habitat. Urbanization and Development: Emerging Futures; UN-Habitat: Nairobi, Kenya, 2016; pp. $171-191$.

23. Bagherian, B. Livable Cities: How Much Green Space Does Your City Have? Available online: https:/ / www. baharash.com/liveable-cities-how-much-green-space-does-your-city-have/ (accessed on 11 July 2018).

24. Vázquez, M. How Much Green Space Does Your City Have? Available online: https:/ / plusnetwork.wordpress. com/2011/07/13/how-many-metres-of-green-space-does-your-city-have/ (accessed on 13 July 2011).

25. Jia, F.; Cheng-zhao, W.; Wall, G.; Li, C. Comparison of Urban Residents' Use and Perceptions of Urban Open Spaces in China, Canada and USA. In Proceedings of the 47th ISOCARP Congress 2011, Wuhan, China, 24-28 October 2011; p. 1.

26. Ashraf, M.A.; Chowdhury, M.S.A. Drainage Planning in the Cities of Bangladesh: Case Study of Drainage and Water Logging in Chaktai Commercial area, Chittagong. J. Bangladesh Inst. Plan. 2009, 2, 49-60. [CrossRef]

27. RAJUK. Preserving Open Spcae for Recreation Livability and Identity; RAJUK: Dhaka, Bangladesh, 2016.

28. Khan, A.M. Revisiting Planning Standards for Recreational Facilities in Urban Areas. In Equality in the City: Making Cities Socially Cohesive; ISOCARP: The Hague, The Netherlands, 2014.

29. Nicol, C.; Blake, R. Classification and Use of Open Space in the Context of Increasing Urban Capacity. Plan. Pract. Res. 2000, 15, 193-210. [CrossRef]

30. Berrill, T.; Environment \& Land Management Pty Ltd. City of Melbourne Open Space Strategy: Technical Report; Environment \& Land Management Pty Ltd.: Melbourne, Australia, 2012; pp. 42-331.

31. Nochian, A.; Tahir, O.M.; Maulan, S.; Rakhshanderoo, M. A comprehensive public open space categorization using classification system for sustainable development of public open spaces. Alam Cipta 2015, 8, $29-40$.

32. Rutherford, J. Classification Framework for Public Open Space; 9781921648335 (Paperback); Department of Sport and Recreation: Leederville, Australia, 2012.

33. Tahir, O.M.; Roe, M. Sustainable urban landscapes: Making the case for the development of an improved management system. Alam Cipta 2006, 1, 17-24.

34. Delgado, E. The City of Marion Draft Open Space \& Recreation Strategy 2006-2016; Marion, C.O., Ed.; South Australian Government Marion: Sturt, Australia, 2006.

35. Minoprio, S.; Macfarlane, P.W. Report on the Draft Master Plan of Chittagong; Chittagong Development Authority, Ministry of Housing and Public Works: Chittagong, Bangladesh, 1961.

36. Zaitzevsky, C. Frederick Law Olmsted and the Boston Park System; Belknap Press: Cambridge, MA, USA, 1983.

37. Nilufar, F. Preserving Open Space for Livability of Dhaka; RAJUK: Dhaka, Bangladesh, 2008; pp. $211-226$.

38. City Hall Kuala Lumpur. Kuala Lumpur Structural Plan 2020. Available online: http://www.dbkl.gov.my/ pskl2020/english/community_facilities/index.htm (accessed on 9 August 2018).

(C) 2018 by the authors. Licensee MDPI, Basel, Switzerland. This article is an open access article distributed under the terms and conditions of the Creative Commons Attribution (CC BY) license (http:/ / creativecommons.org/licenses/by/4.0/). 